\title{
CONSIDERAÇÕES SOBRE A HOMOGENEIDADE COMO PRESSUPOSTO PARA A TUTELA COLETIVA DE DIREITOS INDIVIDUAIS
}

\author{
CONSIDERATIONS ABOUT THE HOMOGENEITY ASSUMPTION FOR THE COLLECTIVE \\ PROTECTION OF INDIVIDUAL RIGHTS
}

Estêvão Mallet

\begin{abstract}
Resumo:
$\mathrm{O}$ art. $8^{\circ}$ : III, da Constituição Federal estabelece a legitimidade extraordinária dos sindicatos para defender em juízo os direitos e interesses coletivos ou individuais dos integrantes da categoria que representam.

$\mathrm{O}$ art. 81 do Código de Proteção e Defesa do Consumidor coloca a tutela processual coletiva no mesmo plano da tutela processual individual, quando diz: "A defesa dos interesses e direitos dos consumidores e das vítimas poderá ser exercida em juízo individualmente, ou a título coletivo."

As ações coletivas voltadas à tutela de direitos individuais tornam-se cada vez mais corriqueiras.

Os direitos homogêneos são direitos subjetivos individuais e se sujeitam à tutela coletiva, exatamente por conta da homogeneidade que apresentam.

As assertivas acima, dentre muitas outras, são detalhadamente explicadas nas considerações que o Dr. Estêvão Mallet tece a respeito da homogeneidade como pressuposto para a tutela coletiva dos direitos individuais, ilustradas por inúmeros exemplos reais e atuais.
\end{abstract}

Palavras-chave: Homogeneidade de interesses. Direitos individuais. Ações coletivas.

\begin{abstract}
:
Art. 8, III, Federal Constitution sets forth the legitimacy extraordinary of the union to assert under judgment the collective and individual rights and interests of the class members representing thereof.

Art. 81, Consumers Protection and Defense Code establishes the collective procedural guardianship in the same intent of individual procedural guardianship, when refers to: "Asserting the consumers and victims interests and rights may be exercised, individually, or collective basis, under judgment."

Collective actions aimed to the individual rights guardianship are increasingly usual. Homogenous rights are individual subjective rights and are subject to the collective guardianship, just because of the homogeneity presented.

Assertions above, among many others, are particularly explained in the Dr. Estêvão Mallet consideration, which discourses about the homogeneity as purpose for the collective guardianship, exemplified by several real and current examples.
\end{abstract}

Keywords: Interests homogeneity. Individual rights. Collective actions.

Doutor e Livre Docente em Direito do Trabalho, Professor de Direito do Trabalho da Faculdade de Direito da Universidade de São Paulo, Conselheiro da Ordem dos Advogados do Brasil - Secção de São Paulo e advogado. 
1. Introdução

Não constitui tarefa fácil a reflexão teórica sobre a tutela processual coletiva de direitos. O processo é normalmente concebido como relação jurídica individualizada, integrada por três sujeitos bem definidos, a saber: o juiz, o autor e o réu. ${ }^{1}$ A própria definição medieval de processo, celebrizada por Bulgaro, parte desse ponto: iudicium est actus trium personarum: iudicis, actoris et rei. ${ }^{2}$ Quando se abandona a perspectiva individual e se passa ao plano coletivo, em que deixa de haver apenas um autor ou apenas um réu, ingressa-se no campo da exceção, o que levou Stephen Yeazell a referir-se, a partir do Direito norte-americano, à class action como "an anomaly" 3 A Suprema Corte dos Estados Unidos, a propósito, assinalou certa feita que "class-action device was designed to allow an exception to the usual rule that litigation is conducted by and on behalf of the individual named parties only" 4

Como desdobramento da visão tradicional, conceitos importantes do processo, como os de parte, litispendência e coisa julgada - para citar apenas alguns -, são estruturados tendo em conta a relação jurídica típica, com apenas um autor e um réu. ${ }^{5}$ Transpostos tais conceitos para as relações processuais de caráter coletivo, ficam eles logo desajustados. Surgem variados problemas e intrincadas dificuldades. Mais ainda, como advertem Cappelletti e Garth, "as regras determinantes da legitimidade, as normas de procedimento e a atuação dos juízes não eram destinadas a facilitar as demandas por interesses difusos por particulares" ${ }^{6}$ Conforme expresso na exposição de motivos do Código modelo de processos coletivos para Ibero-América, "o processo tradicional não se presta à defesa dos direitos e interesses transindividuais" 7

$\mathrm{Na}$ verdade, não somente o processo tradicional não se presta à defesa dos direitos e interesses coletivos ou transindividuais. Os conceitos a ele associados também se mostram inadequados às necessidades inerentes às formas coletivas de tutela processual. Se, por exemplo, quem propõe a ação é o legitimado $\mathrm{A}$, em favor de certo grupo de pessoas, havendo já ação proposta pelo legitimado $\mathrm{B}$, em favor do mesmo grupo, configura-se litispendência ou ambas as ações podem tramitar ao mesmo tempo, sem nenhuma limitação? A aplicação mecânica e simplista do conceito do art. $301, \S 1^{\circ}$, do

Cf. MOREIRA, José Carlos Barbosa. A proteção juridica dos interesses coletivos. In: Temas de direito processual - Terceira série. São Paulo: Revista dos Tribunais, 1984. p. 173.

2 A propósito, MARQUES, José Frederico. Instituições de direito processual civil. Rio de Janeiro: Forense, 1958. v. II, n. 294, p. 79.

3 From medieval group litigation to the modern class action. New Haven: Yale University Press, 1987. p. 8.

4 Califano v. Yamasaki (442 U.S. 682); a passagem transcrita encontra-se a p. 701.

5 Cf. o prefácio de René David na obra Accès a la justice et état-providence. Paris: Econômica, 1984. p. 4.

6 Acesso à justiça. Porto Alegre: Sergio Antonio Fabris Editor, 1988. p. 50.

7 Cf, ainda sobre o ponto, CAPPELLETTI, Mauro. L'acesso alla giustizia dei consumatori em Dimensioni della giustizia nella società contemporanee. Bologna: Il Mulino, 1994. p. 129. 
CPC, forjado para o processo individual típico, levaria a admitir-se o processamento de ambas as ações. Afinal, entre elas não se verifica a tríplice identidade (eadem personae, eadem res e eadem causa petendi), consideradas as partes em cada processo. Mas a solução é claramente insatisfatória no plano coletivo. Havendo concorrência de ações coletivas em favor de certo grupo, os beneficiários finais da tutela são os mesmos, a despeito da diversidade de partes no processo. ${ }^{8}$ Por isso, teve a jurisprudência de deixar de lado a solução clássica, ao avaliar a configuração, no plano coletivo, de litispendência. Passou a adotar conceito mais elástico de parte, relacionado não com os sujeitos formalmente envolvidos no processo, mas com os "beneficiários dos efeitos da sentença" ${ }^{9}$ É, aliás, a solução referendada pelo art. 30, do Código modelo de processos coletivos para IberoAmérica, elaborado pelo Instituto Ibero-americano de direito processual, em que se lê, no art. 30: "Litispendência - A primeira ação coletiva induz litispendência para as demais ações coletivas que tenham por objeto controvérsias sobre o mesmo bem jurídico, mesmo sendo diferentes o legitimado ativo e a causa de pedir" E a jurisprudência trabalhista vai ainda além, para afirmar a litispendência inclusive entre ação individual, proposta pelo titular do direito, e a ação coletiva, proposta por algum legitimado. ${ }^{10}$

8 A propósito, MANCUSO, Rodolfo de Camargo. Jurisdiçâo coletiva e coisa julgada: teoria geral das ações coletivas. São Paulo: 2006. p. 475 e ss.

9 STJ - 5 T., REsp n. 925.278/RJ, Rel. Min. Arnaldo Esteves Lima, julg. em 19.06.2008 in DJe de 08.09.2008. Ainda no mesmo sentido, cf. a seguinte outra decisão: "O aspecto subjetivo da litispendência nas ações coletivas deve ser visto sob a ótica dos beneficiários atingidos pelos efeitos da decisão, e não pelo simples exame das partes que figuram no pólo ativo da demanda”. (STJ - 5 T., RMS n. 24.196/ES, Rel. Min. Félix Fischer, julg. em 13.12.2007 in DЛU de 18.02.2008 p. 46). Também assim, em doutrina, MANUS, Pedro Paulo Teixeira. A litispendência e a substituição processual no processo do trabalho: ação ajuizada pelo sindicato na condição de substituto processual e ação distinta ajuizada pelo empregado substituído com mesmo pedido. Revista do Tribunal Superior do Trabalho, Brasília, v. 74, n. 3, p. 43-46, jul/set 2008.

Representativos da diretriz indicada são os acórdãos do Tribunal Superior do Trabalho assim ementados: "Embargos. Litíspendência. Ação coletiva. Sindicato. Substituto processual. 1. Há litispendência entre a ação individual e a ação coletiva intentada pelo Sindicato se comuns a causa de pedir e o pedido. A ausência de identidade física de partes processuais não exclui a litispendência, visto que existe uma identidade de partes materiais, uma vez que o direito vindicado pelo Sindicato é de titularidade do empregado. 2. Inexistência de afronta ao artigo 301, e parágrafos, do CPC. 3. Recurso de embargos não provido" (TST- SDI I, E-EDRR n. 764.371/01.1, Rel. Min. João Oreste Dalazen in DJU de 04.08.2006) e "Litispendência em relação às diferenças do adicional de insalubridade. A iterativa, notória e atual jurisprudência desta Corte tem se posicionado no sentido de haver litispendência entre a ação individual do empregado e aquela proposta por sindicato na qualidade de substituto processual, quando possuírem o mesmo objeto". (TST $-2^{\mathrm{a}} \mathrm{T}$., Proc. RR n 79.396/2003-900-02-00, Rel. Min. José Simpliciano Fontes de F. Fernandes in DJU de 19.09.2008). Há também precedentes nos Tribunais Regionais, como o seguinte: "Litispendência...Provada a anterioridade da ação ajuizada e a identidade da matéria, relativamente à ação posterior, impõe-se o acolhimento da preliminar suscitada, inteligência do $\S 3^{\circ}$ do art. 267 do CPC, a par do seu relevante interesse, já que se destina a evitar a prolação de decisões conflitantes e contraditórias. Irrelevante a circunstância de se tratar de anterior ação proposta pelo Substituto Processual (não havendo identidade de partes), seja porque o trabalhador possa ter figurado no rol de substituidos e, ainda que assim não fosse, dele seria o direito material em debate. Hipótese em que a extinção do processo é de rigor - art. 267, V, do CPC" (TRT 15 Reg., 5 a T., Ac. n. 25.259/97, Rel. Juiz Luís Carlos Cândido Martins Sotero in DJSP de 15.09.1997, p. 58). Em sentido contrário, todavia, já decidiu o Tribunal Superior do Trabalho: "Litispendência. Inexiste litispendência entre a ação ajuizada 
Não surpreende, diante do exposto, se tenha escrito, na primeira metade do século XX, quando se começou a considerar a importância da tutela coletiva de direitos: "the problem of fashioning an effective and inclusive group remedy is... a major one" "

\section{Coletivização da tutela processual}

Sem embargo das dificuldades apontadas, provocadas pela inadequação dos conceitos tradicionais do processo para disciplina da tutela coletiva, a tendência à coletivização do processo, em alguma medida ou em certos setores, é inexorável.

É preciso ter em conta, em primeiro lugar, que a sociedade de massa leva, naturalmente, à existência de litígios repetitivos, envolvendo grande número de pessoas. Um único ato atinge, com frequência, grande número de sujeitos, por conta da sua repetição. Nas palavras de Cappelletti, "gli interessi 'diffusi' rappresentano un fenomeno tipico, e di crescente rilievo, nella società moderne, caratterizzate dal passagio da un'economia prevalentemente basata su rapporti individuali ad un'economia in cui lavoro, produzione, scambi e consumi, ma anche educazione, turismo, comunicazioni, assistenza sociale e previdenziale, ecc., sono fenomeni 'di massa' " ${ }^{12}$ Pense-se, para melhor ilustrar a situação mencionada, em cláusula ilegal inserida em contrato de prestação de serviços, elaborado por empresa envolvida em uma miríade de relações jurídicas individuais, com os mais diferentes consumidores, em todo o território nacional. As lesões serão contadas aos milhares ou mesmo aos milhões. Querer tratar cada um dos litígios provocados pela ilicitude da cláusula contratual em um diferente processo, de natureza individual, além de abrir espaço para soluções conflitantes, em prejuízo da segurança jurídica, é desfuncional e anti-econômico. Como anota Garry D. Watson, "where the alternative to a class action is repetitive litigation relating to the same events, the results is judicial inefficiency" 13

Ademais, há ilícitos cuja discussão judicial somente faz sentido quando considerada a lesão do ponto de vista transindividual. Insignificantes no plano individual - de modo a não estimular a busca judicial da reparação para a lesão sofrida -, adquirem magnitude apenas vistos coletivamente. Nas palavras de Hein Kötz, "le préjudice qui resulte du comportement illicite peu être, tel...qu'il soit ressenti par un grand nombre

pelo sindicato profissional e a ajuizada pelo trabalhador, individualmente, objetivando o recebimento de diferenças salariais decorrentes de planos econômicos, porquanto não se verifica a identidade de partes, não sendo também idêntico o objeto. Recurso do reclamante provido" (TST, $2^{\text {a }}$ T., Ac. n. 6.512/97, Rel. Min. Moacyr Roberto Tesch in DJU de 12.09.1997, p. 44.042).

" KALVEN JR., Harry; ROSENFIELD, Maurice. The contemporary function of the class suit. The University of Chicago Law Review, v. 8, 686, 1940-41.

12 La dimensione sociale: l'acesso alla giustizia. Dimensioni della giustizia nella società contemporanee cit., $\mathrm{p}$. 86.

13 Class actions: the Canadian experience. Duke Journal of Comparative \& International Law, v. 11, p. 269, 2001 
de personnes à la fois, mais que, en ce qui concerne chaque individu pris isolément, il soit si faible que pour aucun cela ne vaille la peine de chercher un rèmede" ${ }^{14} \mathrm{Um}$ bom exemplo talvez seja o das microlesões individuais, que atingem grande número de pessoas, milhares ou milhões delas. $\mathrm{O}$ fabricante de açúcar que comercializa o seu produto em embalagem de 1 quilograma e subtrai alguns poucos gramas de cada embalagem - 2 ou 3 gramas - certamente lesa vários indivíduos. Cada um dos consumidores, embora lesado pessoalmente, em toda compra feita, não tem estímulo suficiente para ir a juízo, a fim de postular, para si apenas, alguma reparação, dada a quase irrelevância do dano individual. Transposta a lesão para o plano coletivo, porém, considerada a venda global de embalagens durante largo período de tempo, sua magnitude torna-se enorme. Assim, somente a tutela coletiva adquire abrangência suficiente para estimular a busca de alguma forma de tutela judicial. Tinha presente a circunstância o Presidente norte-americano Franklin D. Roosevelt quando, em sua mensagem ao Congresso, sobre o veto aposto à Lei Logan-Walter, assinalou: "Individual shippers could not cope in the courts with great railroads corporations over excessive charges that were small in single cases but important in the aggregate" 15 Em outras palavras, ficando-se apenas no plano individual, mais difícil se torna a propositura de ação ressarcitória. ${ }^{16}$ Surge inevitavelmente um obstáculo econômico - conquanto não-jurídico - para o acesso efetivo à justiça. ${ }^{17} \mathrm{Via}$ de consequência, deixa também de haver, para o causador da lesão, o desestímulo ao cumprimento da lei, decorrente da possibilidade de questionamento judicial do comportamento ilícito. Afinal, se cresce a perspectiva de permanecer sem reparação o enriquecimento contrário ao

14 La protection en justice des interets collectifs: tableau de droit compare. Accès a la justice et état-providence cit., p. 95.

86 Cong. Rec. 21.501 apud KALVEN JR., Harry; ROSENFIELD, Maurice. The contemporary function of the class suit... cit., p. 686.

16 A dificuldade agrava-se sempre que os custos para a propositura da ação individual não sejam negligenciáveis. Assinalou o juiz McHugh, em decisão tomada pela High Court da Austrália: “...the recent cases have been more liberal in allowing representative actions to proceed. In the Age of Consumerism, it is proper that this should be so. The cost of litigation often makes it economically irrational for an individual to attempt to enforce legal rights arising out of a consumer contract. Consumers should not be denied the opportunity to have their legal rights determined when it can be done efficiently and effectively on their behalf by one person with the same community of interest as other consumers. Nor should the courts'lists be cluttered by numerous actions when one action can effectively determine the rights of many" (Carnie and Another v. Esanda Finance Corporation Limited, F.C. 95/004, [1995] HCA 9; (1995) 182 CLR 398; a passagem transcrita encontra-se no item 10, do pronunciamento do juiz Mc Hugh).

17 O relatório final sobre o acesso à justiça, apresentado junto ao Governo Britânico, para subsidiar a elaboração das Civil Procedures Rules, assinalava, no tocante às ações coletivas: "Unlike the position in some other common law countries, there are no specific rules of court in England and Wales for multi-party actions. This causes difficulties when actions involving many parties are brought. In addition to the existing procedures being difficult to use, they have proved disproportionately costly. It is now generally recognised, by judges, practitioners and consumer representatives, that there is a need for a new approach both in relation to court procedures and legal aid. The new procedures should achieve the following objectives: (a) provide access to justice where large numbers of people have been affected by another's conduct, but individual loss is so small that it makes an individual action economically unviable...". 
direito, aumenta, para o causador da lesão, o estímulo econômico para a prática de ato que lhe propicia ganho, ainda que de forma ilegítima. É preciso, contudo, eliminar "the fruits of unlawful activity", conforme adverte Edward H. Cooper, ${ }^{18}$ o que se consegue também com a coletivização da tutela judicial. ${ }^{19}$ A Suprema Corte da Província canadense de Ontário teve oportunidade de assinalar, bem a propósito, a importância que a class action desempenha na "modification of behaviour of actual or potential wrongdoers who might otherwise be tempted to ignore public obligations" ${ }^{20} \mathrm{E}$ a Suprema Corte da Califórnia não deixou de enfatizar: "By establishing a technique whereby the claims of many individuals can be resolved at the same time, the class suit both eliminates the possibility of repetitious litigation and provides small claimants with a method of obtaining redress for claims which would otherwise be too small to warrant individual litigation" ${ }^{21}$ Por isso a doutrina afirma que as class actions "enforce the law by requiring a violator to bear the costs it inflicts on a class of victims, costs it otherwise could avoid because each victim's injury is too small to warrant suit". 22

Ao lado de outros que ainda poderiam ser mencionados, ${ }^{23}$ há mais um fundamento para a utilização de formas coletivas de tutela, fundamento que é especialmente importante no Direito do Trabalho. Muitas vezes a lesão a direito trabalhista não suscita reação individual, durante a vigência do vínculo de emprego, muito mais por conta do receio, sério e fundado, de comportamento retaliatório do empregador. Se não há proteção eficaz contra a rescisão imotivada do contrato de trabalho, prefere o empregado, receoso de comprometer o emprego, deixar de lado seu crédito, para não perder a sua fonte de renda, única ou principal. Permanece inerte, em tal cenário, não por incúria e tampouco pela irrelevância econômica da lesão, mas por temor de sofrer dano maior. Eis o motivo pelo qual o Tribunal da Relação de Lisboa afirmou que a situação de subordinação do empregado constitui um fator "limitativo do livre exercício dos seus direitos" ${ }^{24} \mathrm{O}$ mesmo motivo explica haver a Corte Constitucional italiana afirmado, com a sentença n. 63, de 10 de junho de 1966, a inconstitucionalidade da regra do art. 2.948, n. 4, do Código Civil,

18 Class action advice in the form of questions em Duke Journal of Comparative \& International Law, vol. 11 (2001), p. 218.

19 Sobre o ponto, TROCKER, Nicolò. Processo civile e costituzione. Problemi di diritto tedesco e italiano. Milano: Giuffrè, 1974. p. 705 e ss.

20 Chadha v. Bayer Inc., 1999 CanLII 14812 (ON S.C.). A passagem transcrita encontra no item 17, da decisão.

21 Richmond v. Dart Industries, Inc., (1981) 29 Cal.3d, 462, 478 [174 Cal. Rptr. 515, 629 P.2d 23]. A passagem transcrita encontra-se a p. 469.

22 JAMES JR., Fleming; HAZAR JR., Geofrrey; LEUBSDORF, John. Civil procedure. Boston: Little, Brown and Company, 1992. p. 556.

23 Para rápida indicação de outros fundamentos para a coletivização da tutela, como eliminação de decisões contraditórias, facilitação da atividade probatória, equilíbrio do poder de negociação dos litigantes etc., cf. CASHMAN, Peter. Class Action Law and Practice. Sydney: The Federation Press, 2007. p. 22-23.

24 Acórdão no Recurso n. 84, de 25.07.84 in NETO, Abílio. Contrato de trabalho: notas práticas. Lisboa: Petrony, 1990. p. 159. 
que estabelecia o transcurso da prescrição durante a vigência do contrato de trabalho. ${ }^{25}$ Pois bem, quando se outorga legitimidade para agir a alguma entidade, como o sindicato profissional ou o Ministério Público, permitindo-lhe postular, em nome coletivo, a reparação de direitos individuais lesados, o problema deixa de existir. Autor da ação não é mais o trabalhador, que pode ser dispensado pelo empregador, mas entidade sobre a qual não tem ascendência direta o empregador e que age em nome de vários empregados, a tornar muito mais difícil a adoção de procedimento retaliatório. Por conseguinte, a ação coletiva, promovida por legitimado extraordinário, funciona como um "rito sem rosto" na feliz expressão de Marcos Neves Fava, "defendendo os direitos violados, sem expor o titular da pretensão, evitando retaliação patronal ou perseguição futura" ${ }^{26}$

Em síntese, se as formas coletivas de tutela de direitos apresentam dificuldades - e é fato que apresentam, como rapidamente indicado no item 1, do presente texto - nem por isso há como deixá-las de lado. São mesmo imprescindíveis, para ampliar o acesso efetivo à justiça e facilitar a proteção judicial de direitos.

3. Tutela coletiva de direitos e o processo civil

A evolução do processo civil, no sentido da coletivização da tutela processual, operou-se de modo constante, com sucessivas inovações legislativas, de crescente importância. No plano teórico, desde cedo Cappelletti e Garth, em conhecido estudo, já relacionavam a segunda onda das transformações voltadas a melhorar o acesso à justiça - depois da primeira onda, de busca de meios para propiciar serviços jurídicos para os pobres - com "o problema da representação dos interesses difusos, assim chamados os interesses coletivos ou grupais, diversos daqueles dos pobres". ${ }^{27}$

No campo legislativo nacional, em 1965 aprova-se a Lei da Ação Popular (Lei n. 4.717/65), em cujo art. $1^{\circ}$, confere-se a "qualquer cidadão" a prerrogativa de "pleitear a anulação ou a declaração de nulidade de atos lesivos ao patrimônio da União, do Distrito Federal, dos Estados, dos Municípios, de entidades autárquicas, de sociedades de economia mista...de empresas públicas, de serviços sociais autônomos, de instituições ou fundações para cuja criação ou custeio o tesouro público haja concorrido ou concorra com mais de cinqüenta por cento do patrimônio ou da receita ânua, de empresas incorporadas ao patrimônio da União, do Distrito Federal, dos Estados e dos Municípios, e de quaisquer pessoas jurídicas ou entidades subvencionadas pelos cofres

2s Coerentemente com a decisão anterior, explicitou a mesma Corte Constitucional, na sentença n. 174 , de 12 de dezembro de 1972, que, havendo óbice à denúncia imotivada promovida pelo empregador, é legítima a fluência da prescrição durante a vigência do contrato de trabalho.

26 Ação civil pública trabalhista: teoria geral. São Paulo: LTr, 2005. p. 33.

27 Acesso à justiça cit., p. 50. 
públicos" ${ }^{28}$ Passados 20 anos, edita-se a Lei da Ação Civil Pública (Lei n. 7.347/85), voltada a tutelar amplo espectro de direitos e de interesses, ${ }^{29}$ com legitimação para agir plural, atribuída a varias entidades, de modo concorrente, a saber, Ministério Público, União, Estados, Municípios e, ainda, associações. ${ }^{30}$ Cinco anos depois, em 1990, surge o Código de Proteção e Defesa do Consumidor. É o passo mais significativo, na medida em que contempla o novo diploma todo um título, o III, voltado à disciplina da defesa coletiva dos interesses e direitos do consumidor. No art. 81 coloca-se a tutela processual coletiva no mesmo plano da tutela processual individual, com a seguinte regra: "A defesa dos interesses e direitos dos consumidores e das vítimas poderá ser exercida em juízo individualmente, ou a título coletivo".

4. Tutela coletiva de direitos e o processo do trabalho

No processo do trabalho seria de se esperar menor dificuldade para a utilização das formas coletivas de tutela processual, por duas razões, pelo menos. De um lado, o dissídio coletivo, previsto já na redação original da CLT, envolve significativa quebra dos postulados inerentes ao processo civil clássico. A decisão nele proferida, embora com a forma de sentença, ostenta atributos próprios de normas jurídicas de outro gênero, por apresentar-se como "un comando generale o astratto", consoante a ponderação de Carnelutti. ${ }^{31}$ A despeito disso, nunca houve grande resistência teórica ao dissídio coletivo entre os estudiosos do processo do trabalho.

De outro lado, a relação de emprego, especialmente nos estágios iniciais do desenvolvimento do Direito do Trabalho, é campo propício ao surgimento de lesões coletivas ou transindividuais. Elas são, no cenário, quase naturais. De fato, sendo característica do modelo industrial de produção a convergência das forças produtivas no âmbito da fábrica, com a consequente reunião de vários trabalhadores, sob a direção do mesmo empregador, é muito mais provável que um único ato, praticado durante a execução do trabalho, atinja grande números de pessoas.

De modo surpreendente, porém, após a figura do dissídio coletivo, o processo do trabalho permaneceu praticamente estagnado em matéria de tutela coletiva de direitos. Quase nada evoluiu, ao contrário do que se viu no processo civil. É certo que o legislador não deixou de cogitar de hipóteses de atuação do sindicato como substituto processual, inclusive para a defesa de direitos tipicamente individuais. A Lei n. 2.275, de 1954, por exemplo, deu nova redação ao parágrafo único do art. 872, da CLT, para

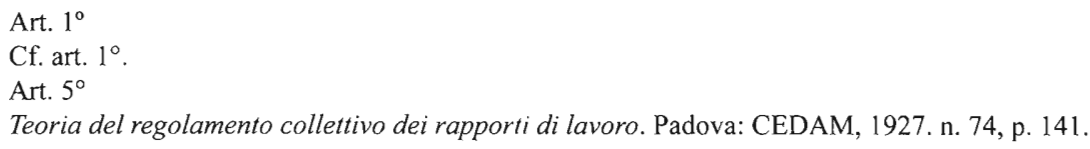


abrir a possibilidade - que antes não existia - de ajuizamento de ação, pelo sindicato, para reclamação de reajuste salarial, estabelecido em sentença normativa. ${ }^{32}$ Também para reclamar pagamento de adicional de insalubridade ou periculosidade permitiu-se a atuação substitutiva do sindicato, a partir do novo texto do art. $195, \S 2^{\circ}$ da CLT, conforme a Lei n. 6.514 , de 1977.

Havia, porém, apenas tais previsões esparsas e casuísticas, ${ }^{33}$ claramente insuficientes, porque deixavam de lado muitas hipóteses importantes em que a tutela processual coletiva poderia e deveria ter lugar, mas não era admitida. ${ }^{34}$ Pior ainda, sujeitavam-se as poucas hipóteses existentes quase sempre a interpretação restritiva, que ainda mais diminuía o campo da tutela processual coletiva. No caso do cumprimento de sentença normativa, consoante o parágrafo único, do art. 872, da CLT, por exemplo, o Tribunal Superior do Trabalho decidiu, em época não muito recuada, restringir os legitimados para agir, de modo a excluir ação proposta por federação sindical. ${ }^{35}$ Ao mesmo tempo, limitou a abrangência dos sujeitos favorecidos pela decisão, para afastar os empregados não associados ao sindicato autor. ${ }^{36}$

\section{A coletivização da tutela processual e a Constituição de 1988}

Como que para compensar a estagnação do processo do trabalho, alheio às formas coletivas de tutela durante largo espaço de tempo, tentou a Constituição imprimir algum avanço. Conferiu ao sindicato, com a regra do art. $8^{\circ}$. inciso III, a prerrogativa de defender "direitos e interesses coletivos ou individuais da categoria, inclusive em questões judiciais ou administrativas"

32 A redação original do art. 872, parágrafo único, da CLT, não fazia referência à atuação do sindicato. Apenas preceituava: "Quando os empregadores deixarem de satisfazer o pagamento de salários na conformidade da decisão proferida, poderão os empregados, juntando certidão de tal decisão, apresentar reclamação à Junta ou Juízo competente, observado o processo previsto no capítulo III deste título, sendo vedado, porem, questionar sobre a matéria de fato e de direito já apresentada na decisão"

33 Não é necessário mencionar outros casos de menor interesse, relacionados com reajustes salariais previstos em leis específicas, como os do art. $3^{\circ}$, $\S 2^{\circ}$, das Leis ns. $6.708 / 79$ e $7.238 / 84$ e do art. $8^{\circ}$ da Lei n. 7.788/89 e o do art. $3^{\circ}$ da Lei n. 8.073/90.

34 Veja-se, por exemplo, o seguinte precedente: "Substituição processual - Legitimidade. O sindicato não possui legitimidade ativa ad causam para postular, na condição de substituto processual, diferenças de décimo terceiro salário decorrentes da integração de gratificação semestral, por inexistir autorização legal para a hipótese sub examen. Recurso conhecido e provido" (TST - $2^{a}$ T., Ac. n. 4.388/97, Rel. Min. Valdir Righetto in DJU de 01.08.97, p. 34.354).

35 Cf., de modo ilustrativo: "Substituição processual - Ação de cumprimento - Art. 872, parágrafo único, da CLT - Federação - Legitimidade. A federação não tem legitimidade para ajuizar ação de cumprimento prevista no art. 872, parágrafo único, da CLT na qualidade de substituto processual da categoria profissional inorganizada" (TST - OE, Ac. n. 304/97, Rel. Min. José Luiz Vasconcellos in DJU de 13.02.98, p. 78).

36 "Por expressa disposição do parágrafo único do art. 872 da CLT, a substituição processual, na hipótese de ação de cumprimento, está limitada aos associados. Recurso de revista provido" (TST - $3^{\mathrm{a}}$ T., Ac. n. 4428/94, Rel. Min. Mendes de Freitas in DJU de 10.02.95, p. 2.114). 
O passo foi largo demais. A jurisprudência, talvez receosa dos excessos que ampla legitimação sindical poderia ocasionar, especialmente em organização sindical estruturada de modo autoritário e sob inspiração corporativista, logo impôs interpretação restritiva do dispositivo constitucional, amparada, inclusive, em pronunciamento da doutrina. ${ }^{37}$ Estabeleceu, passados poucos anos da aprovação do texto constitucional, não haver, no inciso III, do art. $8^{\circ}$, previsão de substituição processual, conforme a dicção do item I, do Enunciado 310, do Tribunal Superior do Trabalho.

Por conseguinte, deixou-se de lado o avanço que a Constituição tentara estabelecer e voltou-se à atomização dos litígios, com a necessidade, para cada lesão a direito trabalhista individual, mesmo com caráter de generalidade, de uma ação específica, ressalvadas as hipóteses, já mencionadas, de admissão expressa de atuação substitutiva do sindicato.

\section{Inversão de sentido}

É claro que a resistência à coletivização da tutela processual, bem retratada no Enunciado 310, não se poderia manter indefinidamente. Não havia - e não há - como resistir à força dos fatos. O crescimento do número de processos tornava insustentável a situação. Enquanto em 1968 a Justiça do Trabalho havia recebido aproximadamente 438.000 processos, dez anos depois, em 1978 , eram 582.000 os processos, com crescimento de $32 \%$. Em 1988, quando promulgada a Constituição, chegou-se ao número de 1.044 .000 processos, em crescimento de quase $80 \%$. Já em 1998 eram 2.400 .000 , ou seja, crescimento de $130 \%{ }^{38}$ Em termos gerais, a cada dez anos, o percentual de crescimento dobrava, em progressão exponencial do número de processos.

Insustentável a atomização dos litígios, diante do vertiginoso crescimento do número de processos individuais, rompeu-se a barreira imposta à substituição processual. De início, sobreveio a revogação do Enunciado 310, por meio da Resolução n. 119, de 2003, do Tribunal Superior do Trabalho. ${ }^{39}$ Pouco tempo depois, o Supremo Tribunal Federal enunciou o caráter amplo da substituição processual atribuída ao sindicato, pela regra do art. $8^{\circ}$, III, da Constituição, em acórdão com a seguinte ementa: "O artigo $8^{\circ}$, III da Constituição Federal estabelece a legitimidade extraordinária dos sindicatos para defender em juízo os direitos e interesses coletivos ou individuais dos integrantes da categoria que representam. Essa legitimidade extraordinária é ampla, abrangendo a liquidação e a execução dos créditos reconhecidos aos trabalhadores. Por se tratar de típica hipótese de

\footnotetext{
37 MAGANO, Octavio Bueno. Substituição processual. In: Política do trabalho. São Paulo: LTr, 1995. p. 207.

38 Dados extraídos do quadro estatístico disponível na página do Tribunal Superior do Trabalho na internet $<$ http://www.tst.jus.br/Sseest/JT1941/JT1941/JT1941.htm>. Acesso em: 06 dez. 2009.

39 DJU de 01.10.2003.
} 
substituição processual, é desnecessária qualquer autorização dos substituídos" ${ }^{40}$ Estava suplantada toda a resistência posta à substituição processual pelo sindicato. Abriam-se, em consequência, novas portas para a tutela processual coletiva de direitos.

\section{Direitos individuais e tutela coletiva}

Como frequentemente ocorre, vencida a resistência às tutelas coletivas, deslocou-se o pêndulo para o extremo oposto. As ações coletivas voltadas à tutela de direitos individuais, antes raras e excepcionais, encaradas sempre com reservas, tornaramse cada vez mais corriqueiras. Foram banalizadas. Passou-se a tentar resolver tudo, mesmo as situações mais distintas, por meio de processos coletivos, interpretando-se de modo bastante amplo a previsão legal. Sob tal prisma, permitiriam o ajuizamento de ação civil pública - principal meio processual de tutela de direitos coletivos - quaisquer direitos individuais decorrentes de "origem comum", condição supostamente suficiente, a partir da definição do art. 81, III, do Código de Proteção e Defesa do Consumidor - consoante interpretação apresentada pela doutrina ${ }^{41}$ e alguma jurisprudência ${ }^{42}$ - para caracterizá-los como homogêneos.

Viram-se, a partir de então, ações civis públicas dos mais diferentes gêneros, propostas tanto pelo Ministério Público do Trabalho quanto por sindicatos. Não faltaram pedidos como os de reconhecimento de existência de contratos individuais de trabalho

40 STF - Tribunal Pleno, RE n. 210.029/RS, Rel. Min. Carlos Velloso, julg. em 12.06.2006 in DJU de 17.08.2007, p. 25.

41 Por todos, cf. NERY JÚNIOR, Nelson; NERY, Rosa Maria Andrade. Código de processo civil comentado. São Paulo: Revista dos Tribunais, 2001. p. 1883, verbis: "O que caracteriza um direito individual comum como homogêneo é sua natureza comum"

42 Cf., por exemplo, a assertiva lançada em acórdão do Superior Tribunal de Justiça, como fundamento para reformar decisão que havia indeferido o processamento de ação civil pública: “...os direitos dos consorciados são caracterizados como direitos individuais homogêneos, pois decorrem de origem comum, ou seja, a nulidade de cláusula contratual" (STJ - 3 ${ }^{\mathrm{a}}$ T., REsp n. 987.382/SP, Rel. Min. Nancy Andrighi, julg. em $01 / 12 / 2009$ in DJe 09/12/2009). 
não- formalizados, ${ }^{43}$ de pagamento de horas extras, ${ }^{44}$ de adicional noturno e de gorjetas, ${ }^{45}$ para mencionar apenas alguns, entre tantos. Afinal, não é difícil considerar configurado, em todos os casos referidos, o pressuposto da origem comum do direito, ante a vinculação dos empregados ao mesmo tomador de serviço.

\section{Origem comum e direitos individuais homogêneos}

O exame mais atento da realidade mostra, todavia, que a mera origem comum não é suficiente para a caracterização dos direitos como homogêneos, ao contrário do que pareceu ao legislador do Código de Proteção e Defesa do Consumidor. Para tomar exemplo expressivo, pode-se considerar a hipótese de horas extras. O não-pagamento de horas extras à totalidade dos empregados decorre certamente de origem comum, por conta do mesmo comportamento omissivo do empregador, dirigido à generalidade de seus empregados. No entanto, nem sempre há homogeneidade dos direitos. No mais das vezes, cada empregado apresenta situação peculiar, inconfundível com a dos demais. Alguns simplesmente não prestam serviço além da jornada contratada. Outros, embora o façam, compensam o excesso de trabalho em um ou alguns dias com redução do horário em dias sucessivos, na forma do art. $59, \S 2^{\circ}$, da CLT, de modo que não têm direito a pagamento adicional. Há ainda os que, mesmo sem compensação de horário, não são credores de nenhum pagamento, diante das excludentes do art. 62, I e II, da CLT. Por fim, para os que efetivamente devem receber horas extras, a variação de tempo excedente impõe exame particularizado de cada situação individual. Não há como, em tal contexto, pretender tratar

43 TRT $21^{a}$ Reg., RO n. 00840-2002-005-21-00-0, Rel. Juíza Maria de Lourdes Alves Leite, Ac. n. 49.206, julg. em 22.01.2004 in DJE/RN n. 10.680, de 27.02.2004.

44 "Legitimidade ativa dos sindicatos. Substituição processual ampla. Direitos individuais homogêneos. A leitura do artigo $8^{\circ}$, inciso III, da Constituição da República deixa patente a legitimidade dos Sindicatos para a defesa dos direitos e interesses coletivos ou individuais da categoria, assegurando a substituição processual ampla. A limitação de atuação dos Sindicatos na propositura de ações coletivas encontra-se na contramão da história, visto que as demandas de massa permitem o acesso ao Judiciário de forma rápida e uniforme, desafogando-o de milhares de reclamatórias individuais. No pleito em que reivindica para os substituídos o pagamento de horas extras e reflexos e outros direitos assegurados por força de norma de ordem pública e de instrumentos coletivos, não está o Sindicato a defender direito coletivo, mas direitos individuais homogêneos, não se podendo sequer cogitar da necessidade de autorização dos substituídos, apresentação de rol, pré-autorização assemblear ou qualquer restrição ao legítimo direito de representação da categoria. E, em se tratando de direito individual homogêneo, está ele inserto nos direitos da categoria, ainda que o seja de pequena fração dela, como no caso dos autos. Ademais, tal interpretação atende à garantia fundamental estabelecida por meio do inciso LXXVIII do artigo $5^{\circ}$ da Lei Fundamental que dispõe sobre a razoável duração do processo e dos meios que garantam a celeridade de sua tramitação" (TRT - $3^{a}$ Reg., $7^{\mathrm{a}}$ T., RO n. 00718-2007-059-03-00-8, Rel. Juiza convocada Mônica Sette Lopes, julg. em 24.04.2008 in DJMG de 13.05.2008, p. 17).

45 TRT - $2^{\text {a }}$ Reg., $12^{\text {a }}$ T., RO n. 00454-2006-048-02-00-3, Rel. Juiz Marcelo Freire Gonçalves, Ac. n. 20090518068, julg. em 02.07.2009 in DOE SP, PJ, TRT 2 $2^{a}$ de 31.07.2009. 
coletivamente os diferentes direitos individuais, para resolver, em um único processo, todos os litígios.

$O$ que se nota, em rigor, é que a simples origem comum dos direitos individuais não basta, a despeito da expressa dicção legal - substancialmente mantida na nova lei do mandado de segurança, aliás ${ }^{46}$-, para que se fale em homogeneidade. A definição do art. 81, III, do Código de Proteção e Defesa do Consumidor, sem embargo do mérito que teve na altura de sua elaboração, pelo avanço que representou, não se ajusta perfeitamente à realidade. A homogeneidade supõe, na verdade, mais do que a mera origem comum dos direitos. Exige um outro elemento, que é indeclinável, ainda que não o tenha mencionado o legislador. Sem tal elemento, configura-se inafastável dilema, quando se pretende tratar coletivamente o direito individual. Convém, antes de aprofundar o conceito de direito homogêneo, examinar rapidamente o dilema indicado.

\section{Direitos individuais heterogêneos e tutela coletiva}

Os direitos homogêneos não são, diversamente do que já se disse, espécie de direitos coletivos. ${ }^{47}$ São, ao contrário, direitos subjetivos individuais. ${ }^{48}$ Apenas se sujeitam a tutela coletiva, por conta exatamente da homogeneidade que apresentam. ${ }^{49}$ Logo, se falta esta homogeneidade, a tutela coletiva, por mais que se queira o contrário e por mais que o legislador pretenda estabelecer algo diverso, torna-se impossível. Forçar a realidade, para tratar coletivamente direitos individuais não homogêneos - ou, caso prefira-se, direitos heterogêneos -, não deixa espaço senão a alternativas que se mostram igualmente insatisfatórias.

De um lado, é possível, como primeira alternativa, chegar à decisão completamente genérica, que nada resolve do litígio. No exemplo antes figurado, de nãopagamento de horas extras à generalidade de empregados, o resultado seria a formulação de sentença em que apenas se enuncia a obrigação de pagar horas extras aos empregados que façam jus ao crédito. Já no caso de falta de registro de empregados, o comando haveria de limitar-se a determinar a formalização dos contratos de trabalho dos trabalhadores que

46 Cf. art. 21, II, da Lei n. 12.016/09.

47 A afirmação consta em acórdão do Supremo Tribunal Federal com a seguinte ementa: "Direitos ou interesses homogêneos são os que têm a mesma origem comum (art. 81, III, da Lei n 8.078, de 11 de setembro de 1990), constituindo-se em subespécie de direitos coletivos" (STF - Tribunal Pleno, RE n. 163.231/SP, Rel. Min. Maurício Corrêa, julg. em 26.02.1997 in DJU de 29.06.2001, p. 55).

48 GIDI, Antonio. Coisa julgada e litispendência em ações coletivas. São Paulo: Saraiva, 1995. p. 30.

49 ZAVASCKI, Teori Albino. Reforma do processo coletivo: indispensabilidade da disciplina diferenciada para direitos individuais homogêneos e para direitos transindividuais. In: Direito processual coletivo $e o$ anteprojeto de Código Brasileiro de Processo Coletivo. São Paulo: Revista dos Tribunais, 2007. p. 34. No mesmo sentido, ainda, MANCUSO, Rodolfo de Camargo. Jurisdição coletiva e coisa julgada. Teoria geral das ações coletivas... cit., p. 313, e SANTOS, Ronaldo Lima. Sindicatos e ações coletivas. São Paulo: LTr, 2008. p. 437. 
prestam serviços com a presença cumulativa dos elementos indicados nos arts. $2^{\circ}$ e $3^{\circ}$ da CLT. Mas sentença que apenas enuncia provimento abstrato não resolve o litígio. Não solve o concreto conflito de interesses trazido a julgamento. Nada acrescenta ao que antes já existia na própria lei. Apenas repete algo que o ordenamento jurídico prescreve. $\mathrm{O}$ que o pronunciamento judicial traz de novo - e tem de trazer de novo - é exatamente a individualização e a especificação da obrigação imposta pela lei. Nas palavras de Lourival Vilanova, "mesmo havendo o legislador previsto o caso mediante norma geral, sua aplicação contenciosa é um processo de individualização. O que enche os poros inevitáveis no esquema abstrato da norma geral é o ato judicial, continuando o processo de produção normativa" 50

A aplicação do direito sempre se faz com a crescente determinação e concretização do comando normativo. Passa-se de um degrau a outro, da constituição para a lei, da lei para a sentença, com a progressiva especificação e a crescente determinação do comportamento devido. A constituição é a primeira norma a estatuir o que é devido e o que não é devido. Mas é também a que apresenta, normalmente, as prescrições mais abertas, mais genéricas e mais indeterminadas. E tem mesmo de ser desse modo, sob pena de, tudo regulando de modo minudente, ficar ela desnaturada. Ao legislador, no degrau imediatamente inferior, é que cabe concretizar um pouco o comando constitucional, para estabelecer regramento mais detalhado, mais preciso, do que é devido e do que não é devido. Mas, ainda assim, fica por definir se, diante de um litígio particular, está ou não configurado o suporte fático de incidência da norma (hipótese normativa), previsto abstratamente na legislação. Por isso, no degrau seguinte encontra-se o juiz que, ao proferir a sentença, estabelece, de modo ainda mais determinado e preciso, o que se deve concretamente fazer, qual o comportamento exigível. Kelsen realça tal aspecto da aplicação do direito quando alude à progressiva concretização do comando normativo, ao passar-se "de um escalão superior para um escalão inferior" "51 Também o faz Engisch ao anotar que o juiz tem "de referir e subsumir um caso concreto a um conceito normativoobjectivo" e, ao fazê-lo, "precisa de realizar uma concretização específica" ${ }^{2}$ Carrion, a seu turno, refere-se ao Poder Judiciário como "encarregado especificamente de adaptar o geral ao singular" ${ }^{53}$ Assim, quando a sentença apenas enuncia previsão genérica, não desce de um degrau para outro. Permanece no mesmo plano, sem nada trazer de novo ao ordenamento jurídico.

$\overline{\text { so }}$ Estruturas lógicas e o sistema de direito positivo. São Paulo: Noeses, 2005. p. 218-219; o itálico foi adicionado.

51 Teoria pura do direito. Coimbra: Armênio Amado, 1962. v. II, n. 45, p. 283.

52 Introdução ao pensamento jurídico. Lisboa: Fundação Colouste Gulbenkian, s. d. p.. p. 240-241.

53 As sentenças incompletas. Madrid: s. e. p. (tese), 1971. p. 105-106. 
Não se ignora, é bom dizer logo, a existência do art. 95, do Código de Proteção e Defesa do Consumidor, com previsão, exatamente para ações coletivas voltadas à defesa de interesses individuais homogêneos, de "condenação...genérica" Mas a dita previsão não significa seja possível pronunciamento com o mesmo grau de generalidade e de abstração da lei. Sentença de tal jaez é, insista-se no ponto, de capital importância aqui, uma contradictio in adjecto, é uma não-sentença. Nada decide e nada resolve. Apenas repete o que na lei já está, sem acrescentar algo ao ordenamento jurídico. Para nada serve.

O que o art. 95 prevê é, tão somente, a sentença com menor grau de concretização do que as demais, em que parte - não tudo! - do que normalmente seria resolvido na fase de conhecimento do processo fica para exame na fase de liquidação, por conta das peculiaridades da tutela coletiva de direitos. Fraciona-se a cognição do juiz. ${ }^{54}$ Resolve-se uma parte do an debeatur, deixando-se a determinação do restante, inclusive do quantum debeatur, para momento subsequente. O provimento, todavia, não é por inteiro genérico e indeterminado, pois fixa, desde logo, tanto a responsabilidade do agente como a sua obrigação de indenizar. ${ }^{55}$ Declara, como escreve Fazzalari, "la sussistenza del diritto ad una prestazione", ainda que "sia ancora controversa la quantità della medisima". 56 Particulariza-se, portanto, o direito aplicável, com o enquadramento da relação individual no âmbito do ordenamento jurídico. Não se fica, pois, na mera repetição do comando legal. Apenas repetir, de modo indeterminado, que se deve observar o que a lei estabelece é a mais perfeita inutilidade. A lei já obriga por si, independentemente de provimento judicial que reitere essa força obrigatória.

Eis a razão para repelir-se a equiparação da força da sentença à força da lei, conforme pretende a dicção do art. 468, do CPC. Melhor é dizer que, a partir da concretização e da determinação realizadas com o julgamento do litígio, em que a disposição abstrata da norma é particularizada, estabelecendo-se o direito aplicável ao caso individual, a sentença se aproxima de uma lex specialis, embora a tanto não equivalha perfeitamente. Carnelutti realça o ponto quando observa que "mentre la legge comanda per una categoria astratta di conflitti di interessi, la sentenza comanda per un conflitto determinato. In ciò sta la sua caratteristica di lex specialis" ${ }^{57}$ Posta de lado a alusão a lex specialis, que suscita alguma resistência da doutrina, pode-se dizer, na linha de Ugo Rocco, que "la sentenza del giudice costituisce una forma particolare e specializzata di norma giuridica, mentre le regole contenute nella legge, costituiscono semplicemente una traccia, più o meno precisa, mediante la quale il giudice addiviene alla formazione della norma completa per il caso

\footnotetext{
CARPI e TRAUFFO. Commentario breve ao Codice di Procedura Civile. Padova: CEDAM, 1994. p. 278. LEONEL, Ricardo de Barros. Manual do processo coletivo. São Paulo: Revista dos Tribunais, 2002. p. 382. Sentenza Civile. In: ENCICLOPEDIA DEL DIRITTO. Varese: Giuffrè, 1989. XLI, p. 1.254.

Lezioni di diritto processuale civile. Padova: CEDAM, 1930. v. 4 - La funzione del processo di cognizione, 1930, n. 384, p. 434.
} 
singolo" ${ }^{58}$ Talvez seja ainda mais exato mencionar, como faz Pedro Batista Martins, que a sentença particulariza-se, em confronto com a lei, pelo seu "conteúdo individualizado" 59 Por isso Liebman, ao caracterizar a condenação - para distingui-la dos demais provimentos judiciais -, anota que nela não está apenas o estabelecimento da sanção, algo que já consta da lei. O que muda com a condenação - anota ele - é que "a sanção, de abstrata e genérica, se transform(a) em concreta e determinada; e é o que faz o processo, de vez que a sanção não se torna automaticamente concreta, mas através da atividade do juiz" 60

Se houvesse como admitir, mesmo sob o pretexto do art. 95, do Código de Proteção e Defesa do Consumidor, decisão genérica e indeterminada, que apenas enunciasse a obrigação de, por exemplo, pagar horas extras aos empregados que façam jus ao crédito ou de formalizar os contratos dos trabalhadores que prestam serviços com a presença dos elementos indicados nos arts. $2^{\circ}$ e $3^{\circ}$, da CLT, não se passaria de um degrau para o outro na atividade de concretização do comando. Permanecer-se-ia no mesmo plano da legislação, sem nada adicionar de certeza à obrigação. Não se concebe, todavia, o exercício da jurisdição de tal modo. Como adverte Liebman, ao julgador cabe tornar concreta a sanção preexistente como "vontade abstrata" ${ }^{61}$ Repetir, em julgamento, o que está na lei não passa, no fundo, de superfetação. O problema permanece inalterado e tudo o que não se resolveu na fase de conhecimento - ou seja, a atividade de concretização da obrigação - ressurgirá ao tempo da liquidação. Para apurar se um determinado trabalhador tem direito a receber horas extras ou se deve ser registrado como empregado, tornarse-á impostergável examinar sua situação individual, em incidente que não terá as características da liquidação própria, senão que se apresentará como verdadeiro processo de conhecimento completo, com ampla discussão sobre os fatos controvertidos.

A outra alternativa, para o dilema decorrente da tentativa de tratar coletivamente direitos individuais não homogêneos, mostra-se igualmente insatisfatória. Envolve a discussão, já na fase de conhecimento do processo, das peculiaridades de cada relação jurídica individual. Na hipótese da ação proposta para forçar o pagamento, a partir de circunstâncias individuais, de horas extras à totalidade dos empregados de dada empresa - exemplo várias vezes referido -, será inevitável facultar ao empregador produzir provas sobre a condição de cada empregado, a fim de que possa ele demonstrar quais não prestam serviço extraordinário, quais compensam o horário, quais se enquadram nas exceções do art. 62, I e II, da CLT, etc. Nenhum sentido faz, porém, semelhante tratamento processual do litígio, em que a ação coletiva se transforma, no fundo, em "a lengthy series

Trattato di diritto processuale civile. Torino: UTET, 1957. I, parte generale, p. 67.

$O$ sentido da lei e a vontade do legislador. Revista Forense, v. LXXI, p. 42.

so Embargos do executado. Oposição de mérito no processo de execução. São Paulo: Saraiva, 1952. n. 70, p. 131.

61 Embargos do executado - oposições de mérito no processo de execução... cit., n. 70, p. 132. 
of individual trials" ${ }^{62}$ Não haverá economia processual, sendo grande o risco de, por conta dos mais variados incidentes, eternizar-se a solução do processo. ${ }^{63}$ Ao fim e ao cabo, terse-á hipótese muito próxima, em termos práticos, de litisconsórcio multitudinário, cuja desfuncionalidade processual encontra-se subjacente à previsão do parágrafo único, do art. 46, do CPC.

E - embora pareça evidente, é sempre bom realçar o ponto - não há como negar a possibilidade de produção de provas pelo réu, a pretexto das inevitáveis dificuldades que daí decorrerão. O processamento da ação coletiva não pode levar à limitação do devido processo legal nem pode privar as partes dos meios de defesa ordinariamente aplicáveis. Como assentou a Corte Constitucional italiana, na sentença $\mathrm{n}$. 53/66, "se si nega o si limita alla parte il potere processuale di rappresentare al giudice la realtà dei fatti ad essa favorevoli, se le si nega o le si restringe il diritto ad esibire i mezzi rappresentativi di quella realtà, si rifiuta o si limita [la] tutela [giurisdizionale])" ${ }^{4}$ Daí já se haver decidido, em célebre precedente inglês, que não é possível admitir o processamento de ação coletiva quando isto implicar a exclusão de uma "defence wich might otherwise be available to the defendant in a separate action" ${ }^{65}$ Os tribunais norte-americano, por sua vez, sempre repeliram a utilização de dados estatísticos, para afastar a necessidade de exame da responsabilidade individualizada em ação coletiva e, via de consequência, permitir o tratamento coletivo do litígio. ${ }^{66}$ Consideram, acertadamente, que a prática viola o direito do réu ao devido processo legal.$^{67}$ Certa vez chegou-se a dizer que tal forma de examinar o litígio nem mesmo poderia ser chamada de julgamento. ${ }^{68}$

10. Caracterização dos direitos individuais homogêneos

Para superar as dificuldades que vêm de ser indicadas, é preciso reconhecer que a homogeneidade dos direitos individuais - pressuposto indeclinável para que possam

62 A expressão consta da decisão proferida em Barnes v. Am. Tobacco Co., 191 F. 3d 127, 149 (3d Cir. 1988).

63 Em Broin v. Philip Morris Inc., a Circuit Court da Flórida assinalou, em ação coletiva nacional, proposta por comissários de bordo, por conta de exposição indireta ao fumo produzido por passageiros, que, mesmo após seis anos de tramitação, era possivel prever ainda "years of additional litigation to adjudicate the individual issues as to all class members" (91-49738 (Fla. Cir. Ct., 5 de fevereiro de 1998). Em outro processo, envolvendo responsabilidade por danos provados pelo consumo de cigarros, a Circuit Court aduziu que o exame particularizado do litígio levaria à pendência do processo até "the 23rd century" (Engle v. R J. Reynolds Tobacco Co., 94-08273 CA-22 - Fla. Cir. Ct., 15 de janeiro de 1998).

64 Apud VIGORITI, Vincenzo. Garanzie costituzionali del processo civile. Milano: Giuffré, 1973. p. 93. No mesmo sentido, ainda, DENTJ, Vittorio. La natura giuridica delle norme sulle prove em Dall'azione al giudicato. Padova: CEDAM, 1983. p. 282.

65 Prudential Assurance Co. Ltd. V Newman Industries Ltd. [1981] 1 Ch 229, 254.

66 Cf., com ampla indicação de precedentes, STIER, Byron G. Resolving the class action crisis: mass tort litigation as network. Utah Law Review, Utah, v. ?? p. 884 ess, 2005.

${ }^{67}$ Cf., por exemplo, a decisão tomada em Cimino v. Raymark Indus. Inc., 151 F. 3d 297, 300 (5th Cir. 1998).

68 In re Fibreboard Corp. 893 F. 2d 706, 712 (5th Cir., 1990). 
eles ser tratados coletivamente - reclama, conforme já assinalado de passagem, algo mais do que a mera origem comum, a despeito da definição do art. 81, inciso III, do Código de Proteção e Defesa do Consumidor, e mesmo do art. 21, II, da nova lei do mandado de segurança. Reclama também que, além disso, predominem as questões comuns sobre as questões individuais. Nas palavras de Salvador Franco de Lima Laurino, "A dimensão coletiva dos direitos individuais homogêneos decorre de dois elementos. O primeiro é a origem comum do direito. Na forma do inciso III do art. 81 do Código de Defesa do Consumidor, são individuais homogêneos os direitos que surgem para uma pluralidade de pessoas em decorrência de um mesmo fato ou ato jurídico. O segundo elemento, que decerto é o mais importante, é a homogeneidade, que significa a prevalência das questões comuns sobre as questões individuais de cada integrante dessa pluralidade de pessoas" ${ }^{69}$

A prevalência das questões comuns sobre as questões individuais é condição imposta há tempos pela legislação norte-americana - que muito cedo começou a tratar da tutela transindividual de direitos - para a tutela coletiva, por meio da class action. A Rule 23, das Federal Rules of Civil Procedure, que disciplina a class action, estabelece, como pré-requisito para a admissão da ação de caráter coletivo, que haja "questions of law or fact common to the class" ${ }^{70}$ É o requisito da origem comum, também mencionado pela legislação brasileira. Ainda assim, a ação somente pode prosseguir como processo coletivo - continua o legislador norte-americano - se, além de satisfeita a condição apontada, "the court finds that the questions of law or fact common to class members predominate over any questions affecting only individual members, and that a class action is superior to other available methods for fairly and efficiently adjudicating the controversy" ${ }^{71}$ É preciso, pois, que predominem as questões comuns sobre as questões individuais, sob pena de ficar obstado o tratamento coletivo do litígio, exigência repetida nas legislações estaduais. ${ }^{72} \mathrm{De}$ modo análogo, o Class Proceedings Act, da província canadense da Colúmbia Britânica, estatui: "In determining whether a class proceeding would be the preferable procedure for the fair and efficient resolution of the common issues, the court must consider all relevant matters including the following: (a) whether questions of fact or law common to the

69 Questões atuais sobre a substituição processual. Revista do TST, Brasília, v. 74, n. 3, p. jul/set 2008, p. 97. No mesmo sentido, ainda, MARCONDES, Roberto Rangel. A importância da participação popular na definição do interesse público a ser tutelado pelo Ministério Público do Trabalho. 2010 São Paulo: s. e. p. (tese), Faculdade de Direito da USP, 2010, p. 85.

70 Rule 23, (a), (2).

71 Rule 23, (b), (3). Embora haja outras hipóteses de cabimento de class action no direito norte-americano, a doutrina anota que, desde a reformulação do texto legal, em 1966, "class actions brought since 1966 have almost all been (b) (3) actions..."(Edwuard S. Labowitz, Class actions in the Federal system and in California: shattering the impossible dream em Buffalo Law Review, vol. 23 (1973-1974), p. 614).

72 Cf, por exemplo, o New York Civil Practice Law and Rules, Section 901, em cuja alínea "a", estabelece-se: "One or more members of a class may sue or be sued as representative parties on behalf of all if:...2. there are questions of law or fact common to the class which predominate over any questions affecting only individual members" 
members of the class predominate over any questions affecting only individual members" 73 Já na Austrália, o Federal Court of Australia Act condiciona a propositura de representative proceeding a que, entre outras circunstâncias, as pretensões das partes favorecidas "give rise to a substantial common issue of law or fact" ${ }^{74} \mathrm{Na}$ Suécia, uma ação coletiva somente é admitida, segundo a Lei sobre Ações Coletivas, de 30 de maio de 2002, se o pedido se fundar em circunstâncias comuns ou de natureza similar ${ }^{75} \mathrm{e}$, ainda assim, desde que não seja a ação inadequada para o exame do pedido, por conta da diferença substancial existente entre os interesses de alguns membros do grupo e os interesses dos demais. ${ }^{76}$

Em outros termos, o que as diferentes legislações mencionadas demonstram é que, se as questões individuais predominam sobre as questões comuns, o que impede tratamento eficiente do litígio de maneira uniforme, não há como intentar ação coletiva. Apenas quando o contrário ocorre - quer dizer, quando as questões comuns predominam sobre as questões individuais - torna-se possível tratar coletivamente a reclamação judicial de direitos individuais. Merece toda atenção, pelo inegável rigor científico e evidente aderência à realidade, a definição de direito individual homogêneo presente no Anteprojeto de lei elaborado pelo Fórum Nacional do Trabalho. ${ }^{77} \mathrm{O}$ avanço, frente à definição lançada no Código de Proteção e Defesa do Consumidor, é manifesto. $\mathrm{O}$ Anteprojeto, no art. 141, II, conceitua os direitos individuais homogêneos, de início, como sendo "os de natureza divisível, de que sejam titulares pessoas determinadas, que tenham origem no mesmo fato ou ato jurídico" No entanto, superando a incompleta redação do Código de Proteção e Defesa do Consumidor, adiciona outra condição fundamental para a caracterização dos direitos individuais homogêneos. Exige, ainda, que fique caracterizada a "prevalência das questões comuns sobre as questões individuais" ${ }^{78} \mathrm{Sem}$ isso, ou seja, havendo tão somente origem comum dos direitos, com prevalência, porém, de questões individuais sobre as comuns, não há homogeneidade. Fica obstado, portanto, sejam os direitos tratados coletivamente. Daí a seguinte previsão, posta no mesmo Anteprojeto, no art. 152, da seção atinente às "ações coletivas para a defesa de direitos individuais homogêneos": "O processo será extinto sem julgamento do mérito quando a origem do direito em que se amparar o pedido não for comum aos integrantes do grupo ou quando as questões individuais prevalecerem sobre as questões comuns"

\footnotetext{
73 Art. 4, (2). Regra praticamente idêntica existe também no Class Proceedings Act, da Província de Alberta, item 5 (2) (a).

74 Sect 33C, (1), (c).

75 Lei sobre Ações Coletivas, Secção 8, n. 1. O texto integral da Lei sobre Ações Coletivas da Suécia encontrase disponível, em versão em inglês, utilizada no presente estudo, no endereço <http://www.sweden.gov.se/ content/1/c6/02/77/67/bcbel f4f.pdf $>$. Acesso em: 31 dez. 2009.

76 Lei sobre Ações Coletivas, Seç̧ão 8, n. 2.

77 Disponivel em $<$ http://www.mte.gov.br/fnt/PEC_369_de_2005_e_Anteprojeto_de_Reforma_Sindical.pdf $>$. Acesso em: 18 dez. 2009.

78 Idem.
} 
11. Predomínio das questões comuns sobre as questões individuais

O predomínio das questões comuns sobre as individuais pode se dar, por exemplo, quando as lesões, causadas a várias pessoas ou a grande número delas, resultam de um fato único, correspondente a um mesmo evento, de que se irradiam diferentes pretensões reparatórias individuais. Foi o que assentou a Suprema Corte dos Estados Unidos ao afirmar o cabimento de class action em casos de acidente aéreo e intoxicação de passageiros em cruzeiros marítimos. Em ambas as situações, afirmou o Tribunal, "proximate cause can be determined on a class-wide basis because the cause of the common disaster is the same for each of the plaintiffs" ${ }^{79}$ No exemplo do acidente aéreo, a posição das vítimas no avião, para mencionar um fato individual, é quase sempre irrelevante para definir o direito à reparação. A responsabilidade pode ser estabelecida "on a class-wide basis" 80

Do mesmo modo, em caso de cobrança indevida, provocada por incorreta interpretação de regras contratuais aplicáveis a vários consumidores, há predomínio da questão comum (legalidade da cobrança) sobre questões individuais. Consoante a United States Court of Appeals for the First Circuit, "the common factual basis is found in the terms of the contract, which are identical for all class members. The common question of law is whether those terms precluded defendant from charging for incoming calls" ${ }^{81}$

É certo que, para a caracterização da homogeneidade dos direitos individuais, as questões suscitadas na causa não precisam, ao contrário do que já se aventou, ser idênticas para todos os membros da classe. ${ }^{82}$ Concebe-se, com certeza, a existência de diferenças, sem que, só por isso, fique obstada a ação coletiva. Como pôde realçar a Corte Suprema da Província canadense de Ontário, no julgamento do caso Mouhteros v. DeVry Canada Inc.: "It is not necessary that the claims or defenses of the class members all raise the same common issues, some differences can be accommodated through the creation of subclasses" 83 O que não faz sentido é processar coletivamente ação em que as questões individuais prevaleçam sobre as comuns. Se o que importa mais, no caso concreto, é

\footnotetext{
459 U.S. 1171.

United States Distric Court, Southern District of Florida - Miami Division em Roxane Maria Borcea vs. Carnival Corporation, processo n. 05-22.968, decisão de 04.05.2006.

81 Smilow v. S.W. Bell Mobile Sys., Inc., processo n. 02-1760, decisão de 07.03.2003.

82 Em julgamento do Tribunal do Trabalho da $4^{a}$ Região, os direitos com origem comum foram caracterizados como sendo aqueles decorrentes de "situações fáticas idênticas" (TRT $-4^{\text {a }}$ Reg., $1^{\text {a }}$ T., RO n. 001660038.2005.5.04.0761, Rel. Juíza Ione Salin Gonçalves, julg. em 26.07.2007), o que soa claramente excessivo.

83 CanLII 14686 (ON S.C.), decisão de 1998. A passagem transcrita encontra-se no item 17 da decisão. Do mesmo modo, decidiu a Suprema Corte da Califórnia: "a community of interest does not depend upon an identical recovery" (Vasquez v. Superior Court (1971) 4 Cal.3d 809 [94 Cal. Rptr. 796, 484 P.2d 964]). Sem divergir, a United States Tenth Circuit Court of Appeals, em DG v. Richard L. Devaughn (n. 09-5093), pontuou: "Factual differences between class members' claims do not defeat certification where common questions of law exist"
} 
o aspecto individual, não o coletivo, deixa de ser apropriada a ação de classe. Se, ao contrário, a individualidade tem menor importância, embora não desapareça nem fique apagada, a ação de classe é adequada ao exame do litígio.

É possível, portanto, o tratamento coletivo de direitos individuais, ante a prevalência das questões comuns, quando, embora não seja único o fato causador das lesões, todas decorrem da repetição, sem mudanças significativas, de eventos substancialmente similares. ${ }^{84}$ Quer dizer, embora as lesões individuais sejam provocadas por fatos distintos, as diferenças não têm relevância a ponto de fazer com que preponderem as questões individuais. Continuam a predominar as questões comuns. Não fica obstado, por conseguinte, o tratamento coletivo do litígio. A legislação australiana cogita expressamente da hipótese. $\mathrm{O}$ Federal Court of Australia Act de 1976, depois de mencionar o conhecido requisito de que, para o processamento coletivo da ação (representative proceeding), é preciso que "the claims of all those persons give rise to a substantial common issue of law or fact" ${ }^{85}$ ressalva: "(2) A representative proceeding may be commenced: (b) whether or not the proceeding: (i) is concerned with separate contracts or transactions between the respondent in the proceeding and individual group members; or (ii) involves separate acts or omissions of the respondent done or omitted to be done in relation to individual group members" ${ }^{86}$ Daí terem assinalado os tribunais australianos, em ampliação ao ditado pela Suprema Corte dos Estados Unidos, no julgado transcrito anteriormente: "The kind of case that can best be run as a representative proceeding is one arising out of a "mass wrong", i. e., out of a single act, omission or course of conduct or the same act, omission or course of conduct repeatedly made or engaged in, and thus a case in which one or a handful of representative parties are able themselves to give the evidence necessary to present a large part of the case for all group members" 87

Em matéria trabalhista, há predomínio de questões comuns sobre as individuais no caso de empregados que trabalham todos próximos de depósito de combustível.$^{88}$ A caracterização da condição perigosa de trabalho prescinde, na hipótese, do exame dos aspectos individuais de cada relação de emprego. Não importa, por exemplo, a função exercida, a antiguidade do empregado na empresa ou o tipo de contrato celebrado.

84 LEONEL, Ricardo de Barros. Manual do processo coletivo. São Paulo: Revista dos Tribunais, 2002. p. 109, e GIDI, Antonio. Las acciones colectivas y la tutela de los derechos difusos, colectivos e indivuales en Brasil: un modelo para países de derecho civil. México: Universidad Nacional Autônoma de México, 2004. p. 62.

85 Sect 33c, (1), (c).

86 Previsão semelhante encontra-se nas Supreme Court Civil Rules da South Australia, de 2006 (cf. CASHMAN, Peter. Class Action Law and Practice... cit., p. 46) e no Class Proceedings Act, de 1992, da província de Ontário, no Canadá. Neste último, no art. 1, assim se definem "common issues": "(a) common but not necessarily identical issues of fact, or (b) common but not necessarily identical issues of law that arise from common but not necessarily identical facts; ("questions communes")"

87 Federal Court of Australia, Silkfield Pty Ltd v James Wong \& Ors, [1998] FCA 1488 (20 November 1998).

88 O exemplo é de LAURINO, Salvador Franco de Lima. Questões atuais sobre a substituição processual... cit., p. 97. 
Tampouco tem relevância o maior ou menor tempo de exposição a risco, já que, como assentado em jurisprudência, apenas a exposição fortuita ou por períodos extremamente reduzidos exclui o direito ao pagamento. ${ }^{89}$ Assim, a questão comum (exposição a risco) predomina sobre as hipotéticas questões individuais, sem maior relevo particular, a permitir o tratamento coletivo da controvérsia. O mesmo se dá em caso de cobrança de valores devidos pelo empregador ao Fundo de Garantia do Tempo de Serviço. Sem embargo do disposto no art. $1^{\circ}$, parágrafo único, da Lei n. $7.347 / 85$, não têm maior significado o valor do salário, a forma de pagamento ou outros aspectos individuais de cada relação de emprego. $\mathrm{O}$ elemento comum - recolhimento ou não dos montantes devidos - permite exame da controvérsia em processo coletivo, sem suscitar o dilema próprio dos casos em que as questões individuais preponderam.

\section{Predomínio das questões individuais sobre as questões comuns}

Quando predominam as questões individuais sobre as comuns, não há como tratar coletivamente o litígio. A impossibilidade não constitui idiossincrasia ou resistência gratuita e indevida às formas coletivas de tutela. Constitui, ao contrário, inafastável decorrência das características próprias dos direitos em debate ou, mais precisamente, da natureza das questões a serem examinadas no processo.

Em caso de contaminação por amianto, por exemplo, negou-se, nos tribunais norte-americanos, a possibilidade de tratamento coletivo de ação tendente a obter indenização para os empregados envolvidos, a partir da ideia de prevalência das questões individuais. ${ }^{90}$ Importam, na hipótese, além da reação de cada indivíduo, o tempo e a intensidade da exposição ao produto. Quem tenha ficado exposto, por poucos instantes, a quantidades reduzidas de amianto normalmente não sofre consequências mais significativas, ao contrário do que se passa com quem tenha sido exposto a quantidades mais expressivas ou, ainda, a quantidades mais modestas, mas por longos períodos de tempo. Logo, para determinar o direito à indenização, torna-se necessário examinar o tempo e a intensidade da exposição de cada pessoa, bem como sua reação individual. Por conseguinte, é manifesto o predomínio das questões individuais, de modo a tornar inviável exame coletivo do problema. Na decisão, assentou o tribunal norte-americano, ao recusar o processamento da ação coletiva: "Taking all these factors into consideration, the Court is convinced that the number of uncommon questions of law and fact would predominate over the common questions, and the case would therefore 'degenerate into multiple lawsuits separately tried". 91

89 Súmula 364, do Tribunal Superior do Trabalho.

90 Yandle v. PPG Ind. Inc., 65 F.R.D. 566, 570-71 (E.D.Tex.1974).

91 Yandle v. PPG Ind. Inc., 65 F.R.D. 566, 570-71 (E.D.Tex.1974). Na fundamentação do julgado lê-se ainda: 


\section{A Corte Suprema da Província canadense de Ontário também negou a} possibilidade de tratamento coletivo de ação ajuizada por força de fraude na celebração de contrato de franquia, envolvendo aproximadamente quarenta contratados. Ainda que a pretensão decorresse, para todos os lesados, do mesmo contrato, as particularidades de cada situação individual, diante da forma como se deu a contratação e das tratativas realizadas, impediam o exame conjunto dos litígios individuais. ${ }^{92}$

"[T]he Pittsburgh Coming plant was in operation in Tyler for a ten year period, during which some 570 persons were employed for different periods of time. These employees worked in various positions at the plant, and some were exposed to greater concentrations of asbestos dust than were others. Of these employees it is only natural that some may have had occupational diseases when they entered their employment for Pittsburgh Corning. There are other issues that will be peculiar to each plaintiff and will predominate in this case, such as: The employee's knowledge and appreciation of the danger of breathing asbestos dust and further, whether the employee was given a respirator and whether he used it or refused to use it. Additionally, the plaintiffs have asserted various theories of recovery against the defendants, and the nine defendants have alleged differing affirmative defenses against the plaintiffs. For example, the statute of limitations may bar some plaintiffs, but not others. During the ten year period the state of medical knowledge was changing, which has a significant bearing on the defendants' duty to warn of dangers". Em outro processo, também envolvendo contaminação por amianto, a Court of Appeals for the Fifth Circuit assinalou: "The 2,990 [asbestos personal injury] class members cannot be certified for trial as proposed under Rule 23(b)(3).. There are too many disparities among the various plaintiffs for their common concerns to predominate. The plaintiffs suffer from different diseases, some of which are more likely to have been caused by asbestos than others. The plaintiffs were exposed to asbestos in various manners and to varying degrees. The plaintiffs' lifestyles differed in material respects. To create the requisite commonality for trial, the discrete components of the class members' claims and the asbestos manufacturers' defenses must be submerged" (In re Fibreboard Corp., 893 F.2d 706 - 1990). A jurisprudência consolidou-se com a decisão da Corte Suprema dos Estados Unidos, no caso Amchem Products, Inc., et al. v. Windsor, em que se decidiu, também em ação de indenização decorrente de contaminação por contato com amianto: "In contrast to mass torts involving a single accident, class members in this case were exposed to different asbestos containing products, in different ways, over different periods, and for different amounts of time; some suffered no physical injury, others suffered disabling or deadly diseases" (512 U.S. 591). Mais recentemente, em Arenas v. El Torito Restaurants, Inc. assinalou-se: “... a class action will not be permitted if each member is required to "litigate substantial and numerous factually unique questions" before a recovery may be allowed"(Cal. App.4th, [No. B211301. Second Dist., Div. Five. Mar. 15, 2010]). Nesta última decisão encontra-se indicação de vários outros precedentes de igual teor, a saber, Acree v. General Motors Acceptance Corp. (2001) 92 Cal. App.4th 385, 397; Vasquez v. Superior Court (1971) 4 Cal.3d 800, 809; Wilens v. TD Waterhouse Group, Inc. (2003) 120 Cal.App.4th 746, 756 e, ainda, Bell v. Farmers Ins. Exchange (2004) 115 Cal.App.4th 715, 742.) (2010).

92 Ontario Supreme Court, Rosedale Motors Inc. v. Petro-Canada Inc., 1998 CanLII 14721 ON S.C. Da fundamentação do julgado extraem-se as seguintes considerações, utilizadas para indeferir o pedido de atuação de um dos lesados como representante dos interesses de todo o grupo: "[28]... The claims of all class members do not turn on a single common representation but rather in large part upon what was said by individual Petro-Canada representatives to individual class members in separate meetings that led to the creation of relatively complex business relationships. [29] As Rosedale puts itself forward as the representative plaintiff, its claim must be taken as the example. Rosedale's case plainly shows there were significant matters pertaining only to Rosedale that would have to be considered when assessing virtually every aspect of the claim of misrepresentation. Rosedale was first invited to consider becoming a Certigard franchisee in 1988. Rosedale retained legal counsel who assisted Rosedale in the negotiation of the agreement. After expressing concerns about the profitability of the franchise concept and other matters of which it now complains, Rosedale was able to negotiate a one-year trial period agreement for a Certigard franchise. The terms of that agreement provided that Rosedale retained the right to terminate the franchise at no cost and take the compensation it would have been entitled to receive by way of severance under the lease agreement. 
Na jurisprudência nacional, de forma semelhante, repeliu-se processamento de ação coletiva voltada a obter reconhecimento de relação de emprego em favor de vários trabalhadores. A ementa do acórdão aduz, de maneira precisa: "A declaração da existência do vínculo de emprego pressupõe a investigação da situação pessoal de cada um dos substituídos, já que para a efetividade do provimento é imprescindível averiguar o concurso dos requisitos do artigo $3^{\circ}$ da Consolidação. A situação não envolve direito individual homogêneo, que, além da origem comum, pressupõe a prevalência das questões comuns sobre as questões individuais de cada substituído. A hipótese é de direito individual puro ou heterogêneo, que não tem dimensão coletiva porque as questões individuais prevalecem sobre as questões comuns. Ao contrário do que ocorre com o direito individual homogêneo, em que a predominância das questões comuns conduz a situação de uniformidade que permite a emissão de provimento genérico e torna desnecessária a identificação dos substituídos até o momento de liquidação da sentença, a efetividade da declaração da existência de vínculo de emprego exige a prévia identificação dos substituídos, já que a eliminação da crise de certeza a que se destina o provimento declaratório depende da cognição de questões individuais de cada um dos trabalhadores. Sem a identificação dos substituídos, o pedido é indeterminado e, de conseqüência, sua apreciação conduziria

This arrangement has obvious relevance to the misrepresentation claim Rosedale is asserting. It provides the lens through which the alleged misrepresentations would have to be viewed. In my view, it demonstrates the difficulty, if not the impossibility, of dealing with the misrepresentation aspect of some 40 commercial agreements between relatively sophisticated parties as if they were all one and the same. Even if there were a finding that in the general sales strategy it adopted, Petro-Canada misrepresented certain important facts, I do not accept that such a finding in the abstract would "move the litigation forward" in a meaningful way. Taking Rosedale's claim as being representative, I must conclude that it would be necessary to consider in detail precisely what each franchisee was told, what significance those statements had in the context of the negotiation as a whole, and what, if any, significance those statements had in relation to the legal nature of the relationship that was created. [30] While these comments relate in particular to the claim based upon misrepresentation, the same considerations apply to the other claims that have been asserted, given their common root in the allegation that the Certigard franchise failed to live up to the expectations induced by Petro-Canada's sales pitch. I would add, moreover, that the claim based on a fiduciary duty would be heavily dependent upon careful review of the nature of the relationship between the individual class member and Petro-Canada. Again, this is apparent from the evidence led on this motion by Rosedale in support of this aspect of the claim referring to the history and nature of the particular relationship the principals of Rosedale had with Petro-Canada. It could not be assumed that other franchisees had the same relationship, particularly in view of the evidence led by Petro-Canada as to the long list of different features and situations of various franchisees, which includes assignees of previous franchisees, former Petro-Canada Certigard employees, franchisees who have renewed their agreements and franchisees who have sold their interest. Similarly, in the context of this action, relief on the basis of unconscionability would call for careful scrutiny of the nature of the relationship between the parties and the nature of the deal they struck and could not be determined on a global class basis" (Ontario Supreme Court, Rosedale Motors Inc. v. Petro-Canada Inc., 1998 CanLII 14721 - ON S.C.). Nos Estados Unidos, a Suprema Corte de Illinois também indeferiu o processamento de class action, em caso de lesão contratual, ante a diferente condição de cada contratante. Aduz o julgamento que "plaintiff class members who were insured under either of these policies would be in a different position than their "like kind and quality" and "pre-loss condition" counterparts regarding the claim that the specification of non-OEM parts constituted a breach of their insurance contract" (Avery v. State Farm Mut. Auto. Ins. Co., processo n. 91494, decisão de 18.08.2005). 
a provimento desprovido de qualquer utilidade" ${ }^{93}$ Não poderia ser de outro modo, pois, como se sabe, a existência ou não do contrato de trabalho não decorre de aspectos formais ou exteriores, como o tipo contratual escolhido pelos sujeitos da relação, mas da maneira concreta como se desenvolve a prestação de serviço, tendo em conta, em particular, o caráter subordinado ou não do trabalho. Logo, torna-se impostergável examinar, caso a caso, a forma segundo a qual se desenvolve o trabalho, de modo a que predominem as questões individuais sobre as questões comuns.

Em outra oportunidade, indeferiu-se, em decisão confirmada pelo Tribunal Superior do Trabalho, ação coletiva em que cobrado o pagamento de horas extras, com o seguinte argumento: "A norma constitucional (art. $8^{\circ} \mathrm{III}$ ), ao assegurar ao sindicato a defesa judicial dos direitos individuais da categoria, não autoriza a defesa de quaisquer interesses individuais, mas sim a defesa coletiva de direitos individuais homogêneos da categoria, cuja titularidade diz respeito a uma coletividade de empregados representados pelo sindicato, abrangendo ou não toda a categoria. No caso dos autos, a legitimidade extraordinária do sindicato da categoria profissional para buscar o pagamento de diferença de horas extraordinárias in itinere e horas à disposição, não tem suporte legal, já que se trata de direitos vinculados à esfera individual de cada empregado, conforme delimitado pela decisão recorrida, que não podem ser quantificados de forma coletiva". ${ }^{94}$

Algumas vezes o predomínio de questões individuais é provocado não pela diversidade fática das situações individuais, mas pela incidência de diferentes legislações, com regulamentação distinta para a mesma hipótese. Em ordenamento jurídico federativo, a competência legislativa local pode tornar impossível o processamento coletivo de ação. Foi a hipótese examinada pela United States Court of Appeals for Fifth Circuit, em ação de âmbito nacional, proposta por devedores hipotecários, sob alegação de violação dos deveres do agente fiduciário. Negou-se a certificação da ação como coletiva, exatamente por conta do regime diferenciado de responsabilidade dos agentes fiduciários em cada Estado norte-americano. Assinalou-se, no julgado: "Even assuming that general fiduciary principles are similar across jurisdictions, Plaintiffs have the responsibility to demonstrate that state law variations do not preclude the certification of a nationwide class. They have failed to do so with respect to the establishment of fiduciary duty" 95

93 TRT 2a Reg., 6a T., RO n. 00825200600302006, Rel. Juiz Salvador Franco de Lima Laurino, Ac. n. 20080226358 in DOE de 09.04-2008.

94 TST $-6^{\text {a }}$ T., RR n. 166/2005-761-04-00.4, Rel. Min. Aloysio Corrêa de Veiga in DJU de 06.06.2008. Em termos análogos, a repelir ação coletiva envolvendo direitos individuais de caráter heterogêneo, cf. TST $-8^{\mathrm{a}}$ T., AIRR n. 702/2007-011-06-40, Rel. Min. Dora Maria da Costa in DJU de 07.11-2008.

95 Casa Orlando Apts., Ltd. v. Fed'l Nat'l. Mortgage Assn., 09-40997, decisão de 14 de outubro de 2010. 


\section{Exame da espécie de questão predominante}

Determinar se, em dada situação concreta, predominam as questões comuns sobre as individuais ou o contrário é, como facilmente se percebe, decisivo. A partir da solução do ponto estabelece-se o cabimento, ou não, da ação coletiva. Mais ainda, apenas quando realmente haja o predomínio das questões comuns sobre as individuais o tratamento coletivo da controvérsia faz algum sentido e leva a resultado útil, segundo se procurou explicar acima. Logo, quando, por erro ou outra circunstância qualquer, se admite ação coletiva, a despeito do predomínio de questões individuais, não se vai além do dilema apontado no item 9 , do presente texto, com prolação de sentença genérica, que nada acrescenta para a solução do litígio, ou com inviabilização prática do processo, pela necessidade - para fugir do pronunciamento genérico - de exame, já em sua fase de conhecimento, das múltiplas particularidades de cada relação jurídica individual.

Sem embargo da importância de que se reveste o problema, não há como o resolver abstratamente. Não existe solução pré-determinada, enunciada a priori, pois não é a espécie de direito reclamado que delimita, em termos absolutos e inafastáveis, o cabimento ou não da ação coletiva. O que importa, em rigor, é a natureza das questões a serem debatidas no processo, ou seja, a extensão do contraditório, consideradas, inclusive, a causa de pedir ${ }^{96}$ e a defesa. $O$ direito reclamado pode ser qualquer um. Se sua cobrança não suscitar o exame preponderante de questões individuais, nada obsta a propositura de ação coletiva. ${ }^{97}$

Assim, não se deve excluir - ao menos não de maneira peremptória - ação coletiva relacionada com a duração do trabalho ou com o pagamento de horas extras, para mencionar casos paradigmáticos, com frequência enfrentados nos tribunais nacionais e já lembrados ao longo do presente texto. Embora se trate de direitos com dimensão normalmente heterogênea - dado que, no mais das vezes, cada empregado apresenta situação específica -, é possível que venham à tona em litígio com predominância de questões comuns. Tudo depende da maneira como se apresenta a ação. Se a causa de pedir, para o pedido de pagamento de horas extras, funda-se em situação fática uniforme, compreensiva de vários empregados, nada obsta o processamento coletivo do processo. Deixa de ter importância a situação particular de cada empregado (questão individual),

$96 \quad$ No RR n. 103900-23.2002.5.03.0033, Relatora a Min. Maria Cristina Irigoyen Peduzzi, a $8^{\text {a }}$ Turma sublinhou a importância da causa de pedir na definição do caráter homogêneo ou não do direito discutido na ação (julg. em 28.10.2009 in DEJT de 03.11.2009).

97 A jurisprudência dominante, contudo, costuma levar em conta, no mais das vezes, apenas a natureza do direito reclamado, para afastar o cabimento de ação coletiva relacionada, por exemplo, com o pagamento de horas extras (cf. TRT -2 $2^{a}$ Reg., $9^{a}$ T., RO n. 01926200731702002 , Rel. Juíza Jane Granzoto Torres da Silva, Ac. n. 20081121363 in DOE de 13.02.2009 e TRT $-4^{a}$ Reg., $5^{\text {a }}$ T., RO n. 0016300-76.2005.5.04.0761, Rel. Juiz Paulo José da Rocha, julg. em 05.07.2007) e com o pagamento de adicional noturno, gorjetas e salários atrasados (TRT $-2^{\mathrm{a}}$ Reg., $12^{\mathrm{a}}$ T., RO n. 00454-2006-048-02-00-3, Rel. Juiz Marcelo Freire Gonçalves, Ac.

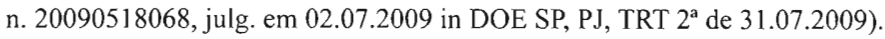


em face do aspecto uniforme da situação fática suscitada. Em caso de cobrança de horas extras, por conta de alegado trabalho em turno ininterrupto de revezamento, em desacordo com o limite estabelecido pelo art. $7^{\circ}, \mathrm{XIV}$, da Constituição, por exemplo, a situação fática prende-se ao regime de trabalho na empresa, não à duração individual do trabalho, ou seja, à situação particular de cada empregado. Não importa, por conseguinte, a jornada de trabalho de cada empregado. Logo, o predomínio da questão comum (o regime de trabalho na empresa) permite o ajuizamento de ação coletiva, dada a menor relevância das condições individuais. Bem por isso a Corte Suprema de Nova Jérsei admitiu class action em que questionada a supressão de intervalos para repouso e alimentação, ajuizada em favor de aproximadamente 72.000 empregados, exatamente pelo fato de decorrer o pedido de procedimento padrão adotado pelo empregador. ${ }^{98}$ Também a Corte Suprema da Califórnia aceitou processar class action para cobrança de horas extras, não pagas em virtude de incorreta classificação adotada pelo empregador, para largo grupo de empregados. A oposição do réu ao exame do pedido veio amparada, como seria de prever, na alegação de que "determining its liability, if any, for unpaid overtime compensation necessarily requires making individual computations of how much time each class member actually spent working on specific tasks" ${ }^{99}$ Entendeu o tribunal, porém, que o não pagamento de horas extras decorria de "deliberate misclassification", adotada como "defendant's policy and practice" ${ }^{100}$ Consignou ainda o tribunal: "owing in part to operational standardization and perhaps contrary to what defendant expected, classification based on job descriptions alone resulted in widespread de facto misclassification" ${ }^{101}$ Ante o caráter genérico do comportamento adotado, tornou-se possível o tratamento coletivo da controvérsia. ${ }^{102}$

98 Iliadis v. Wal-Mart Stores Inc., N.J., n. A-69, decisão de 31.05.2007. No mesmo sentido, admitindo class action na hipótese de alegada não concessão regular de intervalo para repouso e alimentação, cf. Jaimez v. Daiohs USA (2010), Cal.App.4th, em que se afirma: "...for purposes of the class certification motion, the predominant common factual issue is whether RSR's (a sigla indica os Route Sales Representatives, quer dizer, os representantes de venda, empregados da empresa demandada na ação) missed meal breaks because First Choice's policy and practice of designating delivery schedules and routes precluded RSR's from timely completing their routes and taking the legally required rest breaks...It is evident that common legal and factual issues predominate over any individual issues with respect to the meal and rest break claims" 
A abrangência da defesa apresentada é também importante para que se decida sobre o cabimento da tutela coletiva. Se a defesa envolver alegação que imponha o exame de questões individuais, relativamente à particular condição dos titulares dos direitos individuais, fica prejudicada a tutela coletiva. Como anota a doutrina, "a representative action may not be permitted where the defendant is entitled to raise separate defenses in respect of the different plaintiffs" ${ }^{103}$ É evidente, no entanto, que, sendo protelatória ou impertinente a alegação relativa a questões individuais, o processo da ação coletiva não fica em nada prejudicado. Incide, no caso, a regra dos arts. 130, do CPC, e 765, da CLT, de modo a justificar-se a desconsideração, no caso, da objeção oferecida na defesa.

De qualquer sorte, não importa, para o cabimento da tutela coletiva, que algumas questões individuais fiquem por resolver em fase subsequente. Há mesmo questões que têm inevitavelmente de ser relegadas para exame posterior. É o que se dá, no caso de horas extras reclamadas pela inobservância do horário reduzido para turnos ininterruptos de revezamento, com o fato de um ou outro empregado não ter direito a pagamento adicional, pelo exercício de função de confiança, na forma do art. 62, II, da CLT. Ainda assim, a questão que predomina é a comum, a saber, a violação, para a generalidade dos empregados, do limite imposto pelo art. $7^{\circ}$, XIV, da Constituição. As questões individuais - que não deixam de existir - manifestam-se de forma apenas residual. Tornam-se, diante da ação deduzida, secundárias e menos importantes. Não constituem motivo, portanto, para que se afaste o cabimento da tutela coletiva. Como assinalado na já citada decisão da Corte Suprema de Nova Jérsei, "the mere existence of remainder issues is insufficient to defeat class certification" 104 E a Suprema Corte da Califórnia, a seu turno, teve ocasião de registrar: "a class action is not inappropriate simply because each member of the class may at some point be required to make an individual showing as to his or her eligibility for recovery or as to the amount of his or her damages" 105

Para determinar a homogeneidade dos direitos leva-se em conta, como dito, a natureza das questões a serem debatidas no processo, ou seja, a extensão do contraditório, consideradas, inclusive, a causa de pedir e a defesa. Não cabe avaliar, portanto - nem se deve

\footnotetext{
103 CASHMAN, Peter. Class Action Law and Practice... cit., p. 99, com citação de precedente do King's Bench. 104 Iliadis v. Wal-Mart Stores Inc., N.J., n. A-69, decisão de 31.05.2007.

105 Employment Development Department et al. v. Betty Ann Boren, n. 24216 [30 Cal.3d 267], decisão de 27.11.1981. Na mesma linha, em outro pronunciamento da Suprema Corte da Califórnia: "the necessity for class members to individually establish eligibility and damages does not mean individual fact questions predominate." (Reyes v. Board of Supervisors, 196 Cal. App. 3d, p. 1278). Confira-se, ainda, aresto da United States Court of Appeals for the First Circuit: "the need for individualized damage decisions does not ordinarily defeat predominance where there are still disputed common issues as to liability...If the class action resolved liability even as to some further narrowed class, this would be a legitimate function" (Tardiff V. Knox County, 04-1065, 04-1165, decisão de 12.04.2004). Também vale mencionar Jaimez v. Daiohs USA (2010), Cal.App.4th, pode-se ler: “...individualized proof of damages is not per se an obstacle to class treatment...It is no bar to certification "that individual class members may ultimately need to itemize their damages"
} 
fazê-lo, pois seria de todo em todo prematuro -, a procedência da pretensão deduzida. ${ }^{106}$ $\mathrm{Na}$ diç̧ão da jurisprudência norte-americana, "in order to determine whether common questions of [law and] fact predominate the trial court must examine the issues framed by the pleadings and the law applicable to the causes of action alleged" ${ }^{107}$ Por conseguinte, a admissão do processamento da ação de forma coletiva tampouco implica juízo favorável relativamente ao mérito, nem mesmo sob a forma de mera delibação, como explicitado, aliás, no Class Proceedings Act, da Província canadense de Ontário. ${ }^{108}$

\section{Decisão sobre o processamento da ação coletiva}

Não é incomum encontrar-se, em algumas legislações, a previsão de momento próprio, no início do processo, para exame da pertinência ou não da ação coletiva. Trata-se da fase de certificação da ação (class certification), que guarda alguma semelhança com a fase de saneamento do processo civil brasileiro. Nos Estados Unidos da América, as Federal Rules of Civil Procedure estabelecem que, "at an early practicable time after a person sues or is sued as a class representative, the court must determine by order whether to certify the action as a class action" ${ }^{109}$ No Canadá, em várias Províncias, há regra semelhante. ${ }^{110}$

No momento da certificação deve-se examinar, além da presença dos vários pressupostos próprios da ação coletiva, o problema da espécie de questões predominantes.

106 A conclusão é pacífica na jurisprudência norte-americana. A Suprema Corte dos Estados Unidos, por exemplo, certa feita decidiu: "nothing in either the language or history of Rule 23 ... gives a court any authority to conduct a preliminary inquiry into the merits of a suit in order to determine whether it may be maintained as a class action" (Eisen v. Carlisle \& Jacquelin (1974) 417 U.S. 156. A passagem transcrita acha-se a p. 177). No mesmo pronunciamento, pouco adiante, pode-se ainda ler: "In determining the propriety of a class action, the question is not whether the plaintiff or plaintiffs have stated a cause of action or will prevail on the merits, but rather whether the requirements of Rule 23 are met". (Eisen v. Carlisle \& Jacquelin cit., p. p. 178). Cf., também, entre outros julgamentos, a seguinte decisão da Corte Suprema da Califórnia: "...we view the question of certification as essentially a procedural one that does not ask whether an action is legally or factually meritorious" (Linder v. Thrifty Oil Co. (2000) 23 Cal.4th 429, 97 Cal.Rptr.2d 179; 2 P.3d 27. A passagem transcrita encontra-se a p. 440), além de mais um julgado de que se extrai, verbis: "In determining the propriety of a class action, the question is not whether the plaintiff or plaintiffs have stated a cause of action or will prevail on the merits, but rather whether the requirements of Rule 23 are met"(Anderson v. City of Albuquerque, 690 F.2d 796, 799 [10th Cir. 1982]). Para arrematar, veja-se Jaimez v. Daiohs USA (2010), Cal.App.4th, já citada várias vezes no presente texto, verbis: "The determination of whether to certify a class does not contemplate an evaluation of the merits"

107 Hicks v. Kaufman \& Broad Home Corp. (2001), 89 Cal.App.4th 908 [107 Cal. Rptr. 2d 761]. A transcrição feita encontra-se a p. 916.

108 Item 5, (5), assim redigido: "Certification not a ruling on merits. (5) An order certifying a class proceeding is not a determination of the merits of the proceeding"

109 Rule 23, (c), (1), (A).

110 Columbia Britânica (Class Proceedings Act, item 4), Alberta (Class Proceedings Act, item 5) e Ontário (Class Proceedings Act, item 5). 
Se predominam as questões individuais, não as comuns, a certificação é negada e a ação não mais prossegue como ação de classe. ${ }^{111}$

Para tomar a decisão, pode-se realizar até mesmo instrução de caráter preliminar, inclusive com elaboração de laudo pericial ou avaliação do valor probatório de laudos particulares elaborados pelas partes. Em American Honda Motor Company, Inc., et al., v. Richard Allen, et al., caso em que se questionava a estabilidade de certo modelo de motocicleta, por conta do desenho do guidão, trouxeram os autores, para justificar o pedido de certificação, laudo elaborado por perito particular, impugnado pelos réus. Deferida a certificação, sem exame do valor probatório do laudo, no recurso os réus postularam o reexame do decidido, com avaliação da prova. Ao acolher o recurso, a United States Court of Appeals For the Seventh Circuit assentou: "when an expert's report or testimony is critical to class certification, as it is here.... a district court must conclusively rule on any challenge to the expert's qualifications or submissions prior to ruling on a class certification motion" 112

A cognição judicial na altura da certificação é ampla, de modo a permitir tanto o deferimento integral do pedido de processamento coletivo da ação como o oposto, ou seja, o indeferimento do pedido de processamento da ação como class action. É também possível que se decida pelo acolhimento parcial do pedido de certificação, com redução da abrangência da classe ou exclusão de certas questões, insuscetíveis de exame em ação coletiva, mantido, porém, o processamento coletivo da ação no tocante a parte dos pedidos. ${ }^{113}$

A decisão relativa à certificação pode ou não comportar reexame imediato, por meio de apelação, a depender das circunstâncias do caso. Nos Estados Unidos da América é pacífico que não existe direito, garantido por lei, à interposição de recurso. ${ }^{114}$ Cabe ao tribunal, examinar, caso a caso, a pertinência do recurso, pois, como decidiu a Suprema Corte, "orders relating to class certification are not independently appealable...

III Cf., na jurisprudência australiana: "...if because of the extent of non-common issues, representative proceedings in the assessment of the court are not the preferable means of dealing efficiently and effectively with the claims, the court will no doubt terminate the representative nature of the proceedings..." (Wong $\mathrm{v}$ Silkfield Pty Ltd. (1999) 199 CLR 255, [33]).

112 Julgamento tomado em 07.04.2010. O inteiro teor da decisão pode ser encontrado em http://caselaw. lp.findlaw.com/data2/circs/7th/09805 lp.pdf.

113 Como exemplo de precedente em que reduzida a extensão coletiva do processo, com modificação da definição da classe, em caso de discriminação contra certos grupos na concessão de fundos públicos para aquisição de moradias ou reformas de imóveis, cf. The United States Court of Appeals for the Third Circuit, n. 03-3488, Gail Watson Chiang v. Ann M. Veneman, julgamento de 20.09.2004. Diante de ambiguidade existente no tocante à abrangência da classe, resolveu o tribunal, verbis: "rather than decertify the class, as the USDA (trata-se do United States Department of Agriculture, verdadeiro réu na ação, já que Ann M. Veneman figurou nela na condição de secretária da entidade) urges us to do, we prefer to take a less drastic course and simply modify the class definition to remove the ambiguity"

114 Em doutrina, cf. Fleming James Jr., Geofrrey Hazar Jr. e John Leubsdorf, Civil procedure cit., p. 570. 
prior to judgment" $115 \mathrm{O}$ julgamento do recurso fica vinculado, portanto, ao conteúdo da decisão. Aceita-se, porém, a recorribilidade imediata quando a decisão tomada leva à extinção do processo ${ }^{116}$ ou quando a decisão de certificação "raises the stakes of the litigation so substantially that the defendant likely will feel irresistible pressure to settle" 117 bem como quando o julgamento do recurso puder levar "to clarification of a fundamental issue of Law" ${ }^{118}$ No Brasil, em processo trabalhista, a solução tem de ser outra. A regra do art. 893, $\S 1^{\circ}$ da CLT, afasta a recorribilidade imediata de eventual decisão interlocutória, tomada sobre o cabimento ou não da ação civil pública. Ainda que o prosseguimento da ação ocorra apenas em relação à parte dos pedidos, e não a todos, excluídos aqueles em que predominam as questões individuais, a interposição de recurso ordinário não é pertinente. ${ }^{119}$ Apenas quando se extinguir o processo, ante o não cabimento da ação civil pública - na forma do já citado art. 152, do Anteprojeto de lei elaborado pelo Fórum Nacional do Trabalho ${ }^{120}$-, há como admitir recurso ordinário desde logo.

No Direito norte-americano, a interposição do recurso, em qualquer hipótese, não impede - ao menos não de pleno direito - o normal prosseguimento do processo. A apelação não tem, em outros termos, efeito suspensivo ex lege. A suspensão depende de pronunciamento judicial. ${ }^{121}$ Produz-se ope judicis.

No julgamento do recurso não fica o tribunal limitado apenas a apenas manter a decisão recorrida ou a reformá-la por inteiro. Aplica-se ao caso a regra encontrada em 28 U.S.C. $§ 2.106 .{ }^{122} \mathrm{O}$ efeito devolutivo é amplo, de modo que pode o tribunal, se lhe parecer adequado, modificar parcialmente o pronunciamento, para alterar os termos da

115 Coopers \& Lybrand v. Livesay (437 U.S. 463). A passagem transcrita encontra-se a p. 470.

116 United States Court of Appeals For the First Circuit, Tilley V. Tjx Cos., Inc., processo n. 03-8001, decisão de 02.10 .2003 .

117 Ainda United States Court of Appeals For the First Circuit, Tilley V. Tjx Cos., Inc., processo n. 03-8001, decisão de 02.10.2003.

118 Novamente United States Court of Appeals For the First Circuit, Tilley V. Tjx Cos., Inc., processo n. 03 8001 , decisão de 02.10.2003.

119 A propósito, em matéria de recurso de revista, mas com considerações aplicáveis também ao recurso ordinário, MALLET, Estêvão. Do recurso de revista no processo do trabalho. São Paulo: LTr, 1995. n. 6.1, p. 41-42.

120 "O processo será extinto sem julgamento do mérito quando a origem do direito em que se amparar o pedido não for comum aos integrantes do grupo ou quando as questões individuais prevalecerem sobre as questões comuns".

121 A Rule 23, (f), estatui, na parte que aqui interessa: "APPEALS. A court of appeals may permit an appeal from an order granting or denying class-action certification under this rule if a petition for permission to appeal is filed with the circuit clerk within 10 days after the order is entered. An appeal does not stay proceedings in the district court unless the district judge or the court of appeals so orders"

122 "The Supreme Court or any other court of appellate jurisdiction may affirm, modify, vacate, set aside or reverse any judgment, decree, or order of a court lawfully brought before it for review, and may remand the cause and direct the entry of such appropriate judgment, decree, or order, or require such further proceedings to be had as may be just under the circumstances" 
certificação concedida, ampliando-a, restringindo-a, modificando a definição da classe ${ }^{123}$ ou, ainda, excluindo certas questões do processo ou incluindo outras, de início afastadas em primeiro grau de juridição.

De qualquer sorte, a decisão tomada no julgamento do recurso, em torno do pedido de certificação, não pode, em regra, ser revista pelo juízo a quo, ao receber novamente o caso, para prosseguimento do processo. Como assentado pela United States Court of Appeals for the Fifth Circuit, em Gene \& Gene v. Biopay LLC, "an issue of law or fact decided on appeal may not be reexamined either by the district court on remand or by the appellate court on a subsequent appeal" ${ }^{124}$ Não prevalece a limitação, porém, quando, ordenado o processamento preliminar da class action, com colheitas de provas para melhor prover sobre o pedido de certificação, fica evidente, após a instrução, a necessidade de modificarem-se os termos da certificação, inclusive para emendar o decidido ou até mesmo para afastar o pronunciamento anterior. Em tal hipótese, registrou a novamente a United States Court of Appeals for the Fifth Circuit, em Gene \& Gene v. Biopay LLC, "the district court can and should do so under Rule 23(c)(1)(C)" 125

\section{Conclusão}

A homogeneidade dos direitos individuais, determinante para a possibilidade de sua tutela dar-se em processo coletivo, supõe mais do que a mera origem comum, como pretende o legislador brasileiro, no art. 81, III, do Código de Proteção e Defesa do Consumidor. Supõe, em acréscimo, a predominância das questões comuns sobre as questões individuais. De outro modo, quando predominam as questões individuais, não há como tutelá-los, de modo útil e eficiente, de forma coletiva. Ainda que se venha a tentar tratar coletivamente o pedido, ou o julgamento não terá como deixar de ser genérico e sem relevância prática ou, caso se busque escapar da excessiva generalidade, o exame das questões individuais fará com que se torne inviável a conclusão, em tempo razoável, do processo. Daí a importância de, em cada caso concreto, resolver-se, tão logo seja possível, se predominam as questões coletivas ou não, para evitar, em caso negativo, inútil exercício da jurisdição.

São Paulo, setembro de 2010.

123 Novamente The United States Court of Appeals for the Third Circuit, n. 03-3488, Gail Watson Chiang v. Ann M. Veneman, julgamento de 20.09.2004, caso em que a modificação da definição da classe, para afastar ambiguidade identificada pelo tribunal, ocorreu no julgamento de recurso de apelação, interposto contra a decisão de certificação.

124 Processo n. 09-31191, decisão de 22.10.2010.

125 Idem, Processo n. 09-31191, decisão de 22.10.2010. 